\title{
The Effects of an Educational Program on Recognition of Atypical Signs and Symptoms of Acute Coronary Syndrome in Women in the Emergency Room
}

Robert E. Wynn Jr.

West Virginia University

Follow this and additional works at: https://researchrepository.wvu.edu/etd

\section{Recommended Citation}

Wynn, Robert E. Jr., "The Effects of an Educational Program on Recognition of Atypical Signs and Symptoms of Acute Coronary Syndrome in Women in the Emergency Room" (2013). Graduate Theses, Dissertations, and Problem Reports. 522.

https://researchrepository.wvu.edu/etd/522

This Dissertation is protected by copyright and/or related rights. It has been brought to you by the The Research Repository @ WVU with permission from the rights-holder(s). You are free to use this Dissertation in any way that is permitted by the copyright and related rights legislation that applies to your use. For other uses you must obtain permission from the rights-holder(s) directly, unless additional rights are indicated by a Creative Commons license in the record and/ or on the work itself. This Dissertation has been accepted for inclusion in WVU Graduate Theses, Dissertations, and Problem Reports collection by an authorized administrator of The Research Repository @ WVU.

For more information, please contact researchrepository@mail.wvu.edu. 
The Effects of an Educational Program on Recognition of Atypical Signs and Symptoms of Acute Coronary Syndrome in Women in the Emergency Room

Robert E. Wynn Jr, MSN, FNP-BC, BCEN
Doctoral Capstone Project submitted to the School of Nursing at West Virginia University in partial fulfillment of the requirement for the degree of

\author{
Doctor \\ of \\ Nursing Practice \\ Susan McCrone, PhD, PMHCNS-BC, Chair \\ Michael Mills, DO, FACEP, Mentor \\ Dan DeFoe, NP, Content Advisor \\ Department of Nursing \\ Morgantown, WV
}

2013

Keywords: acute coronary syndrome, women, delay in treatment, outcomes 


\title{
Abstract \\ The Effects of an Educational Program on Recognition of Atypical Signs and Symptoms of Acute Coronary Syndrome in Women in the Emergency Room
}

\author{
Robert E. Wynn Jr, MSN, FNP-BC, BCEN
}

According to the American Heart Association (2010), in the United States every 36 seconds someone dies from heart and blood vessel disease. The Centers for Disease Control and Prevention (2007) estimate that one in six deaths in the US is related to coronary artery disease. When diagnosed with acute coronary syndrome, which is an acute event, resulting from CAD, appropriate treatment greatly reduces the risk of refractory ischemia, need for urgent revascularization, and death. Women are less likely to be urgently diagnosed with acute coronary syndrome, receive thrombolytic therapy, or undergo percutaneous coronary intervention than men, thereby increasing their mortality and morbidity (Bell et al., 1999). There is a need to educate the providers in a rural hospital's emergency department on the atypical signs and symptoms of acute coronary syndrome in women that present to the ED to facilitate emergent treatment. The objectives of the educational program were to increase provider knowledge about the atypical signs and symptoms of ACS with which women present to the ED as measured by an increase in CORE measures: TNKase in less than 30 minutes from arrival in the ED, number of women who received ASA in the ED, and EKG in less than 10 minutes from arrival at the ED.

This capstone project used a one group pretest - posttest quasi-experimental design with a convenience sample of ED providers. The total number of eligible provider participants was 75. Fifty-four (72\%) participated in the 39 minute educational intervention and completed both the pre and post-test. There was a $30 \%$ increase in provider knowledge from pre to post test, $\mathrm{p}<0.001$. There were 23,385 patients seen in the ED during the intervention time frame. Of those, 1,182 met criteria for inclusion. There was a $52 \%$ increase in women who received TNKase in less than 30 minutes from their arrival time in the ED, a $0.8 \%$ increase in the number of women who received ASA in the ED and a 4\% decrease in obtaining an EKG in less than 10 minutes. The intervention proved to be successful in increasing the knowledge of providers in the recognition of atypical signs and symptoms of ACS, increasing the number of women who received ASA in less than 10 minutes, increasing TNKase administration in less than 30 minutes, and minimally increasing EKG administration. Further follow-up is warranted on the impact of the intervention longitudinally. 


\section{Table of Contents}

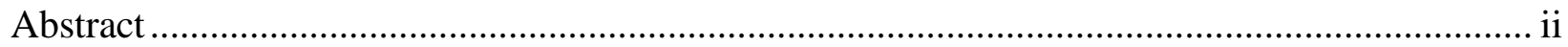

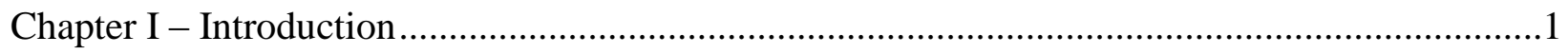

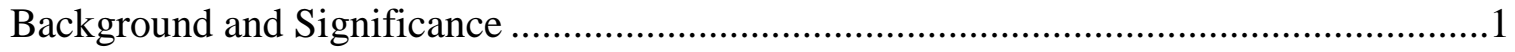

Contributing to the Problem...................................................................................

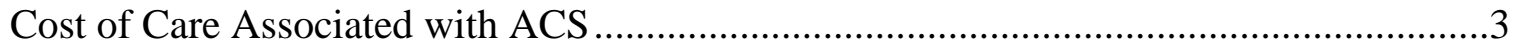

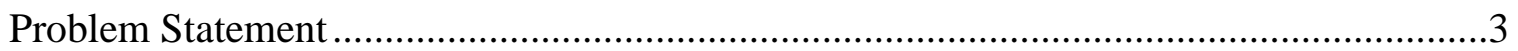

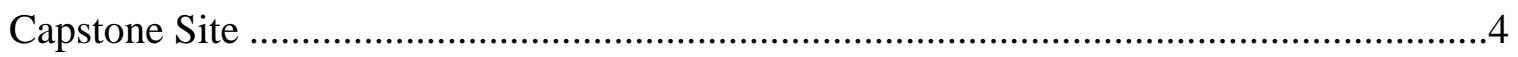

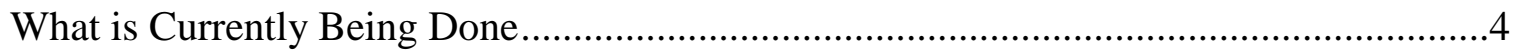

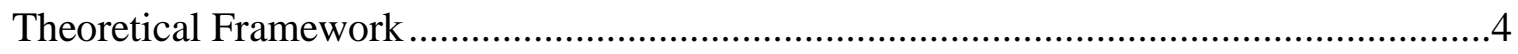

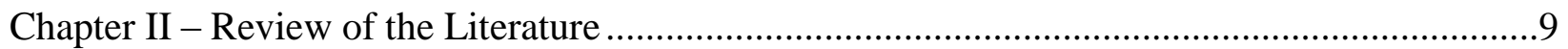

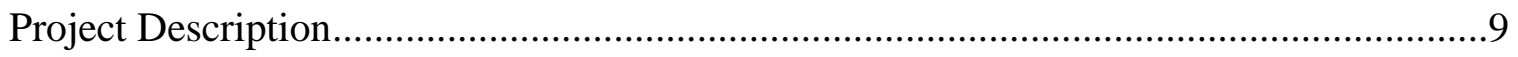

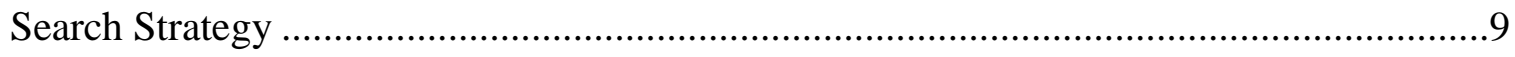

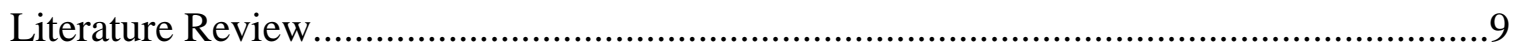

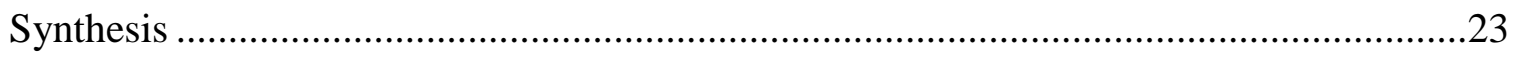

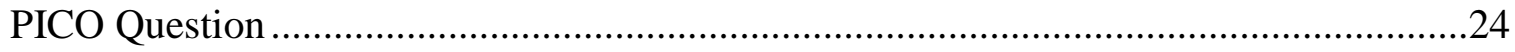

Congruence of Organizations Strategic Plan to Project...............................................24

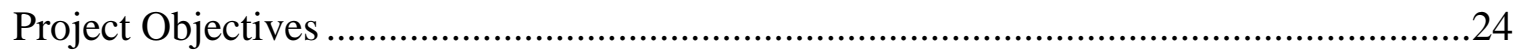

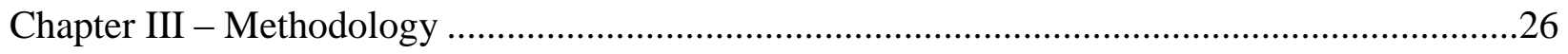

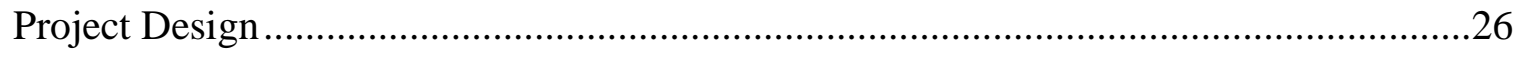

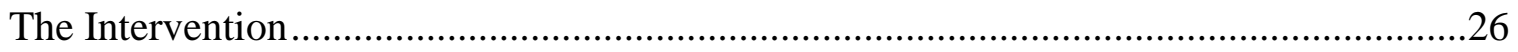

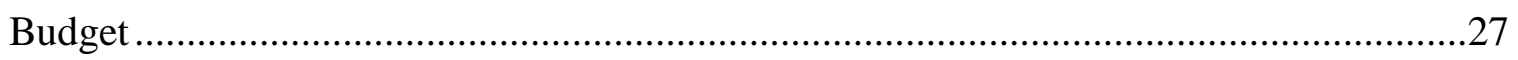

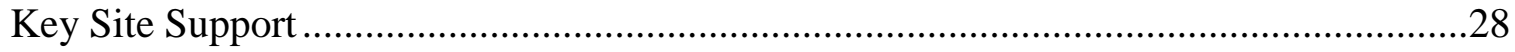




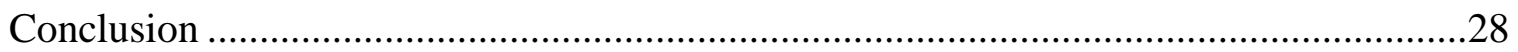

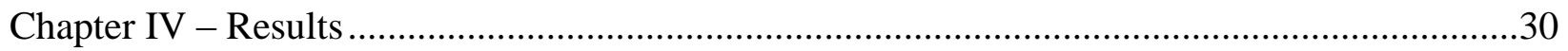

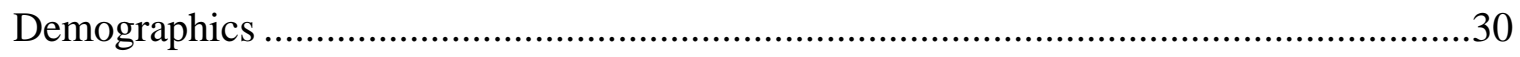

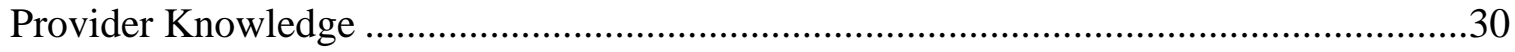

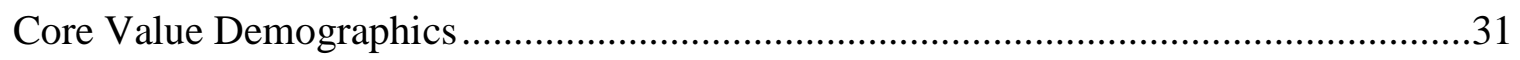

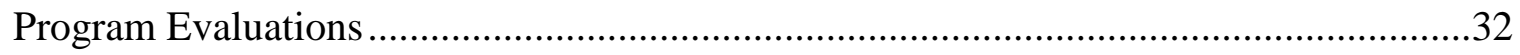

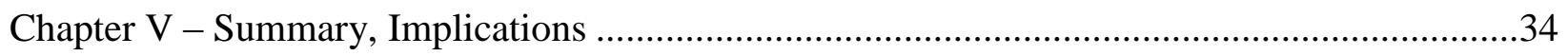

Congruence with Theoretical Framework …....................................................... 34

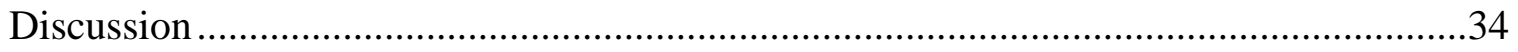

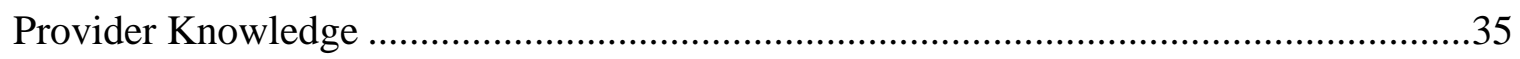

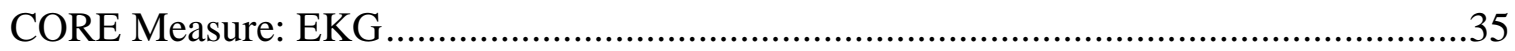

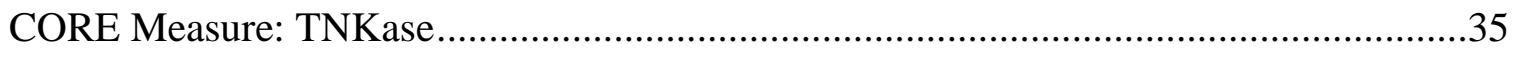

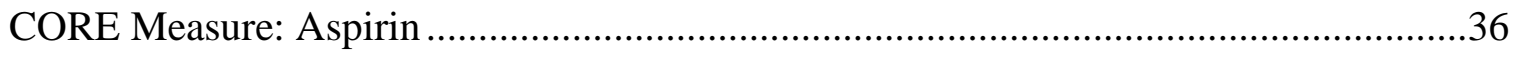

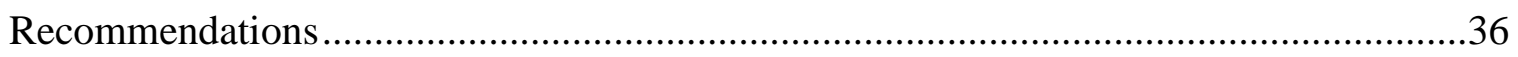

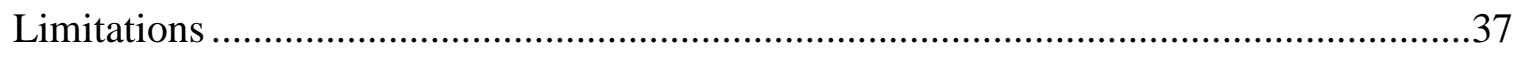

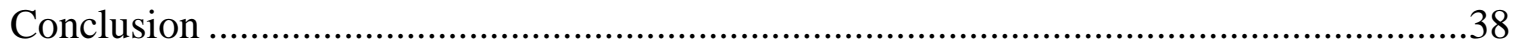

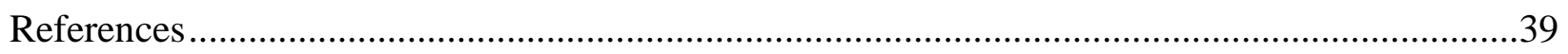

List of Tables

Table I - High Risk Behavior for CAD …...................................................44

Table II - Mercer County Behavioral Risk Prevalence Report ...................................45

Table III - ACS in Women Intervention Participant Characteristics and Demographics .46

Table IV - Provider Knowledge, Pre-Test / Post-Test Scores......................................47

Table V - Population and Population Age ........................................................49 


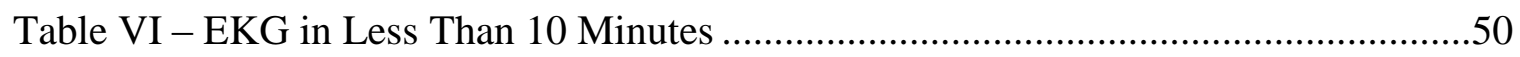

Table VII - TNKase Administration Less Than 30 Minutes........................................52

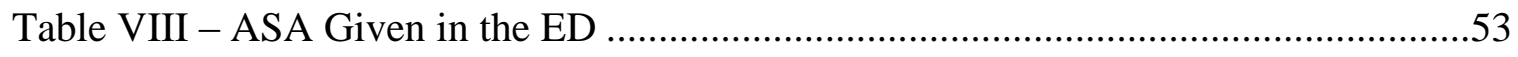

List of Appendices

Appendix A - Scientific Evidence Table................................................................54

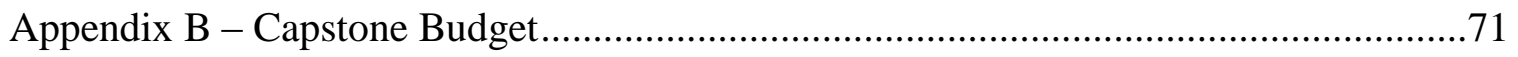

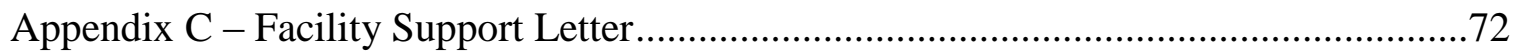

Appendix D - Pre-Test / Post-Test ................................................................ 73 


\section{CHAPTER I - INTRODUCTION \\ Background and Significance}

According to the American Heart Association (2010), in the United States every 36 seconds someone dies from heart and blood vessel disease. The Centers for Disease Control and Prevention (2007) estimate that one in six deaths in the US is related to coronary artery disease. When diagnosed with acute coronary syndrome, which is an acute event, resulting from CAD, appropriate treatment greatly reduces the risk of refractory ischemia, need for urgent revascularization, and death. Women are less likely to be urgently diagnosed with acute coronary syndrome, receive thrombolytic therapy, or undergo percutaneous coronary intervention than men, thereby increasing their mortality and morbidity (Bell et al., 1999). Delays in coming to the hospital at the onset of ACS symptoms play a large role in the treatment that is received by women. Forty percent of delays in coming to the hospital once symptoms of ACS are noticed are attributed to knowledge deficits in women themselves and lack of insurance, type of symptoms, physician's inability to recognize atypical symptoms in women, age, and social support (Gao et al., 1997).

In 2009, WV ranked first in the prevalence of adults diagnosed with a heart attack with more than $6.5 \%$ occurrences compared to the national average of $4.4 \%$. In 2010 , WV ranked second in the prevalence of adults diagnosed with a heart attack with more than $6.3 \%$ occurrences compared to the national average $4.0 \%$. Mercer County, WV, one of 18 counties in WV, has the second highest five-year average death rate from CAD $(307.0-339.9 / 100,000)$. Mercer County reported a crude death rate $(373.3 / 100,000)$ from CAD, which is higher than any other cause of death (WV Bureau for Public Health, Health Statistics Center, 2012). According to the WV Bureau for Public Health, Health Statistics Center (2012), the prevalence for heart 
attacks and angina was higher among West Virginians 65 years and older, who had less than a 15,000 dollar annual income, and who had less than a high school education. In 2009 and 2010, men in West Virginia had a higher prevalence of heart attacks than women: (Men: 8.6\% (95\% CI: 7.4-9.9) in 2009; 8.0\% (95\% CI: 6.7-9.3) in 2010: Women: 4.5\% (95\% CI: 3.8-5.2) in 2009; 4.7\% (95\% CI: 3.9-5.6) in 2010 (WV Bureau for Public Health, Health Statistics Center 2012).

\section{Contributing to the Problem}

Co-morbidities related to CAD in rural Appalachia are higher than other parts of the US and include: obesity, hypertension, dyslipidemia, non-insulin dependent diabetes, physical inactivity, and decreased cardiovascular fitness (Salob, n.d.). The total population of obese people in WV was $30.3 \%$ in 2008, which ranked 25th in the US, and two thirds of all adults between 2007 and 2008 were considered overweight or obese. In 2008, West Virginia had a higher incidence of heart attack and angina than the US population $14.2 \%$ and $8 \%$ compared to 4.3\% and 4.4\% (WV Bureau for Public Health, Health Statistics Center, 2009). In the same year, WV ranked eighth in the nation with the highest number of adults with diabetes at $11.2 \%$. Thirtythree percent of WV adults were diagnosed with hypertension, which ranked 26th highest in the nation in 2007 (West Virginia Behavioral Risk Factor Survey Report, 2009). Just over $42 \%$ of adults in WV had high cholesterol, which was ranked the highest in the nation. In WV $26.5 \%$ of the population smoked at least some or every day, which in 2008 was the second highest in the nation. Thirty-one percent of WV adults did not participate in leisure time physical activity or exercise. Women in WV were less likely to participate than men. In 2007 and 2008, WV had the highest number of residents that were disabled from either, physical, mental, or emotional problems. This figure was higher than any other state in the nation (25.9\% and $29.4 \%)$. (West Virginia Behavioral Risk Factor Survey Report, 2009). Note high risk factors in Table I. 
According to the 2004-2008 Behavioral Risk Factors and Health Conditions by County report (WV Bureau for Public Health, Health Statistics Center 2009), compared to other counties in West Virginia , Mercer County's population had a higher prevalence of heart attacks, angina, and strokes (15.8\% vs 13.55). Mercer County residents were less obese and had more smokers than the state average for the reporting period (25.6/26.7\% vs. 29.6/18.4\%). Hypertension, diabetes awareness, and physical inactivity all ranked higher in Mercer County than the national average: (see 2004-2008 Mercer County high risk factors for CAD in Table II).

\section{Cost of Care Associated With ACS}

In the US, more than 425 thousand deaths and over 1.2 million new or recurrent acute coronary syndromes cases, at a cost of $\$ 151.6$ billion a year, were reported between 2005 and 2007 (CDC, 2010). Arnsdorf et al. 2009 suggest that a woman who has no significant obstructed coronary vessels (less than $50 \%$ obstruction) will cost $\$ 750,000$ in health care during her lifetime. These costs include emergency department (ED) visits, hospitalizations, and repeat procedures, and are related to symptoms of ACS such as chest pain and shortness of breath leading to disabilities, and future cardiac events.

\section{Problem Statement}

There is a need to educate the providers and nursing staff at a rural hospital's emergency department in Southern West Virginia on the atypical signs and symptoms of acute coronary syndrome in women that present to the ED to facilitate emergent treatment. Additionally, the hospitals CORE measures following the Centers for Medicare and Medicaid Services guidelines (Centers for Medicare and Medicaid Services 2012) that include ten minute door to electrocardiogram, aspirin administration, and thrombolysis medication administration within 30 minutes from arrival in the ED need to be improved. 


\section{Capstone Site}

The capstone project was conducted at Princeton Community Hospital (PCH), a rural hospital located in Southern West Virginia. PCH has a 128 in-patient bed capacity and a 30 bed ED. Last year PCH ED provided services to over 50,000 patients. From September1, 2012 thru February 28, 2013, the ED provided services to 23,385 patients, 1182 who were at least 18 years old and were given a diagnosis of chest pain, myocardial infarction, ST elevated myocardial infarction (STEMI), non-STEMI, angina, non-cardiac chest pain, chest wall pain, and ACS.

\section{What is Currently Being Done?}

Following the Centers for Medicare and Medicaid Services (CMS) recommendations, Princeton Community Hospital (PCH) has established CORE measures that include door to electrocardiogram (EKG), aspirin administration, and thrombolysis medication administration within 30 minutes from arrival in the ED. Currently, the ED is below the bench mark set by the hospital's administration. Projected outcomes of this project were that the triage staff would expedite women with complaint of chest pain (including atypical symptoms) into the main ED, and second, the ED nursing staff and providers would emergently evaluate, treat, and disposition women with complaints of chest pain to identify those with ACS in an effort to decrease mortality and morbidity. Through the proposed educational intervention for the providers, it is expected that the scores would improve to at least the bench mark.

\section{Theoretical Framework}

The theoretical framework that was chosen for this capstone project is Rogers' Diffusion of Innovation Theory (DIT). Rogers DIT has been used in many areas such as agriculture, international development, public health, and education. The idea that is being used in this project is "interventions can be designed to invite productive process adoptions so that fidelity of 
outcomes is heightened, not lessened" (Dearing, 2009, p. 15). This framework was chosen because of the theory's ability to determine the adoption of clinical behaviors through diffusion, which include innovation, style of communication, steps in decision making, and social content.

There are three basic types of knowledge that are needed for an innovation. Awarenessknowledge, which is the knowledge that the information of an innovation exists, was delivered to the participants through flyers, in introductory meetings before the intervention and during the intervention. In this project, this was measured by a comparison of the pretest and posttest scores on the knowledge test. Awareness knowledge was expected to propel the individual into the next two stages. How-to knowledge is the knowledge that is needed for the individual to use the innovation. During the intervention, the participants were instructed on the atypical signs and symptoms of ACS with which the women present to the ED. Their application of this knowledge was measured pre and post intervention by an analysis of the CORE measures. Finally, principle knowledge is the information on how the functioning principle of the innovation will work. The participants were given evidence based practice guide lines developed by American Heart Association (AHA), American College of Cardiology (ACC) (Adams et al., 2011) and CORE measures set forth by the hospital following CMS recommendations(Centers for Medicare and Medicaid Services, 2012) to show them how to implement best practices for women who present with ACS.

The persuasion stage is when the individual or group develops a positive or negative attitude towards the innovation. During this stage, the individual seeks more information on the innovation and finds ways that the innovation can be incorporated into his or her own practice. An important part of the innovation was supplying the participants with information that they needed to make their decision to adopt or reject the innovation (Rogers, 2003). 
The decision stage of the innovation is when the individual decides to adopt or reject the innovation. The decision stage usually comes from trying out the innovation on a limited basis to see if it achieves the intended goal. By supplying the participants with positive feedback and the results of the assessed data, this helped the participants to adopt the innovation (Rogers, 2003).

The implementation stage is when the individual actually puts the innovation into practice instead of simply thinking of how it will work. A long period of time may be required before the innovation is considered to be "the way we do it". At this point the innovation is considered to be adopted and no longer a new idea (Rogers, 2003).

The confirmation stage is when individuals seek information to confirm that they made the right decision. During this stage by receiving negative feedback about the innovation, the individual can reject the innovation and go back to the pre-innovation stage. Thus it is important to provide continued communication of positive results about the individuals' performance based on the assessed data (Rogers 2003). Having the willingness and ability to adopt an innovation depends on the participant's knowledge, persuasion, decision, implementation, and confirmation.

Diffusion is the spread of a new idea into a social system. It is accomplished through communication by certain channels (the way the information gets from one person to the next) over time. In the proposed intervention, communication of the innovation occurred through scheduled meetings and flyers. The innovation known as the new idea or practice is adopted by the social group at different rates based on the characteristics. There are five attributes of an innovation. Relative advantage is the degree to which the individual believes that the new innovation is better than the "old way". This was influenced by providing information on the use of evidence based practice guideline for ACS and studies that suggested the different signs and symptoms with which the woman presents to the ED. Compatibility is the degree to which new 
information or innovation is perceived to be consistent with the past experiences and values of the individual. By comparing old and current guidelines, the participants were given the information that allowed them to see that the innovation is a continuation of what is currently being done. Complexity is the degree to which the individual perceives that the innovation is difficult to use. Participants were given practice guidelines to help them understand the innovation through the use of visual aids. Trialability is the degree to which the individual will use the innovation on a limited basis. Triability is encouraged by the investigator and the participants who generally have the ability to influence other members of the group so that the innovation will be adopted. Observability is the degree to which the results are visible to the group. This was accomplished through sharing improved scores in the data that was gathered from the areas that were assessed in the intervention (Rogers, 2003).

Diffusion and adoption were integral parts of this intervention. The participants were given scientific, evidence-based practice guideline and a synthesis of the literature in the population at risk to decrease poor outcomes in women with ACS brought on by reducing delays in recognition and treatment by healthcare providers. The adoption of the guidelines and knowledge gained from the educational program were assessed over time through the provider's post intervention test scores and retrospective chart reviews.

Through the use of Rogers' Diffusion of Innovation theory, the investigator was able to determine those participants that fit into the innovators, early adopters, early majority, late majority, and laggards' categories. Additionally, the investigator was able to assess the reason for the late majority and laggards rejecting Rogers' five stages of adoption. By determining the category and stage of the participants using Rogers DIT, the investigator was able to intervene with the late majority and laggards to reduce anxieties to adoption through reducing personal 
uncertainty with new information. Second, the investigator increased the perception of the participants of the later stages in comparison to the innovators, early adaptors, and early majority that are believed to be more credible. Finally, the investigator increased social pressures from the early majority onto the late majority and laggards ensuring adoption of the intervention (Dearing, 2009). 


\section{CHAPTER II - REVIEW OF THE LITERATURE \\ Project Description}

\section{Search Strategy}

A search of the National Guideline Clearinghouse, CINAHL, PubMed, Medline, Annals of Internal Medicine, and the Cochrane Library was performed to identify the best evidence for decreasing the delays in the diagnosis and treatment of ACS, more specifically in women. Key words included: ACS, women, delay in treatment, and outcomes. There were no limitations placed on settings or language. The initial search of all databases using the key word "ACS in women" yielded a total of 718,738 hits. The search was then narrowed by "delays in treatment of" which yielded a total of 51,160 hits; again, the search was narrowed by adding "outcomes" which lowered the number of hits to 38,874 . Finally, the search was limited by using dates from the years 1990 to 2011. Articles were excluded if they did not have the key terms ACS in women, delays in treatment, and outcomes. Snowballing was also used. A total of eighteen documents met inclusion criteria.

\section{Literature Review}

A critical appraisal was conducted on all documents. The Scottish Intercollegiate Guideline Network (2008) was the appraisal tool for the 18 documents including one systematic review (Adomaityte, Khalid, Messineo, Papadakos, \& Qayyum, 2008), four randomized control trials (Afzal et al. 2009; Aiken et al. 2009; Clark et al. 2005; Davidson et al., 2009) eleven cohort studies (Akhter et al., 2009; Arslanian-Engoren. 2004: Barrett-Connor et al. 2003; Bell et al., 1999; Bugiardini et al., 2011; Buring et al., 2008 Chaitman et al., 1994; Gao et al., 1997; Curtis et al., 2002; Goldberg et al., 2001; Krumholz et al., 2002) and one case control study (Brogan et al., 2006). 
The Appraisal of Guidelines for Research \& Evaluation (AGREE) (2001) was the appraisal tool used for the clinical practice guidelines. The clinical practice guidelines (Adams et al., 2011; Ardissino et al., 2007) are the most up-to-date tools used in the treatment of patients with ACS. Most major items in the domain of the guidelines had scientific rigor for use in practice. The guideline also had a process for review and methods for up-dating. The National Guideline Clearing House provided two relevant national guidelines for the management of ACS (Adams et al., 2011; Ardissino et al., 2007). These guidelines provide physicians and allied health professionals such as NP's and PA's with a set of guidelines to treat patients with angina, non-STEMI (ST segment elevation myocardial infarction) and STEMI among other cardiac related diagnoses. There is an evidence table attached as Appendix A, which reviews the findings of the appraisals.

Aitken et al. (2009) completed a twelve month randomized controlled trial with a sample of 3,522 participants with CAD to determine the effects of an education and counseling intervention on knowledge, attitudes, and beliefs about ACS including the appropriate response to symptoms. The aim of the trial was to reduce pre-hospital delays in seeking emergent care when symptoms of ACS developed. The results of the trial did not meet the intended aim of the study as there was little change in seeking care with the intervention group delay time (median=2.20 hours) and the control group delay time (median=2.25 hours) not being significantly different. However, there were positive and significant differences in the knowledge, attitudes, and beliefs about ACS at three and twelve months in the intervention group compared to the control group $(\mathrm{p}=.0005)$. The participants in the intervention group had higher perceived control over their CAD, which was associated with positive attitudes $(\mathrm{p}<.0005)$. The control group experienced a higher level of anxiety with lower levels of knowledge $(\mathrm{p}<.05)$, 
attitudes ( $\mathrm{p}<.05)$, and beliefs ( $\mathrm{p}<.0005)$. The trial concluded that the intervention did increase participants' knowledge, attitudes, and beliefs about ACS and their response to ACS symptoms. Additionally, the study found that with perceived control over CAD, participants had more positive attitudes than those with high anxiety, which were associated with less knowledge, less positive attitudes, and beliefs about ACS. Strengths of the study were: clearly focused question, well covered description of methodology, and assessed study quality. Weaknesses were that methodology, protocols, and outcome definitions differed among the groups.

Afzal et al. (2009) completed a six month randomized control trial of 3,031 patients experiencing ACS who either underwent early ( $\leq 24$ hours after randomization) or delayed ( $\geq 36$ hours after randomization) invasive interventions. The aim of the trial was to determine whether there was a difference in both primary (death, MI, or stroke at six months) and secondary (death, MI, or refractory ischemia after six months) outcomes in early vs. delayed invasive interventions. In the early intervention group, $97.6 \%$ underwent coronary angiography compared to $95.7 \%$ of the participants in the delayed group. The trial found that there were significant differences between the early vs. delayed groups for preventing primary outcomes ( $9.6 \%$ vs. $11.3 \%)(\mathrm{p}=0.003)$. However, $33.3 \%$ of the participants categorized as high risk did not show a significant difference in the primary outcomes between early vs. delayed intervention (hazard ratio, $0.65 ; 95 \%$ confidence interval $(\mathrm{CI}), 0.48$ to 0.89 ). In the other $66.6 \%$ of the participants categorized as low-to-indeterminate risk, there were significant differences in primary outcomes (hazard ratio, $1.12 ; 95 \% \mathrm{CI}$, [0.81 to 1.56$] ; \mathrm{p}=0.01$ ). In the secondary outcomes, $9.5 \%$ of the patients in early intervention groups vs. $12.9 \%$ of patients in the delayed group either died, had an MI, or had refractory ischemia (hazard ratio, $0.72 ; 95 \% \mathrm{CI}, 0.58$ to $0.89 ; \mathrm{p}=0.003)$. The trial concluded that there was not a significant difference in preventing 
primary outcomes except in the high risk patients; there was, however, a significant difference in preventing secondary outcomes at six month with early invasive intervention. Strengths of the study were: a clearly focused question, randomization, concealment, blinding, and the use of reliable outcome measures. Even though unlikely with a sample size so large, $\mathrm{N}>3000$, the authors of the RCT listed one limitation of the trial as it being underpowered.

Adomaityte and colleagues (2008) conducted a systematic review (SR) of ten trials comprised of 10,648 patients that compared death or MI outcomes with non-STEMI ACS. The aim of the research was to evaluate whether routine invasive strategies compared to selective invasive strategies improved cardiac outcomes. In the review, patients were separated into two categories either routine invasive strategies or selective invasive strategies with 5,330 and 5,318 patients respectively. All participants presented with typical angina symptoms and frequently had ischemic change on electrocardiogram. Of the routine group, $15.9 \%$ either had a non-fatal MI or died compared to the selective group where $17.5 \%$ either had a non-fatal MI or died (relative risk, 0.09 [CI, 0.74 to 1.08$]$ ]). The researchers concluded that routine invasive strategies did not reduce poor outcomes including death from non-fatal MI. The strengths of this SR were a clear focused question, a rigorous literature search, and a well described methodology. Limitations of the review were that the data was heterogeneous and insufficient to determine the aim of the study's methodology and protocols. In addition, outcome definitions were different among the trials.

Krumholz, Ordin, Radford, Rathore, and Wang (2002) used a retrospective cohort analysis of chart-abstracted data on 143,444 Medicare patients. The aims of the study were to determine if there was a variance between men and women who underwent cardiac catheterization following a myocardial infarction (MI) and to determine the appropriateness of 
the procedure using clinical guidelines. The analysis found that there was a significant difference between men and women receiving cardiac catheterization following an MI (46.5\% vs 35.7\% respectively) $(\mathrm{p}<0.001)$. However, the analysis also showed that there was not a significant difference in men and women who either had a strong or weak indication for the procedure $44.6 \%$ vs $44.1 \%$ strong indication ( $p>0.2$ ), and $18.0 \%$ vs $16.5 \%$ weak indication $(p=0.096)$. The significant difference was found when indicators for the procedure were equivocal. Men were more likely than women to undergo the procedure $(42.5 \%$ vs $39.4 \%)(p<0.001)$. The strengths of the study were: a clearly focused question, comparable groups, clearly defined outcomes, and identified confounders. Weaknesses of the study were: the appropriateness of catheterization was based on a clinical guideline not from the causes of a mechanical defect, the guidelines for catheterization may not have reflected EBP standards, and the investigators relied on retrospective abstraction of medical records and may have missed undocumented clinical indications for the catheterization.

Bell et al. (1999) used a retrospective, randomized medical record review of 631 charts of patients that had undergone a coronary angiography in thirteen hospitals in New York City. The aim of the review was to determine if there were differences in those who had received needed revascularization among women, ethnic minorities, and the uninsured when there was on-site availability of revascularization. Only $74 \%$ of the patients who met criteria received cardiac revascularization. There were no significant differences by sex, ethnicity, or payer status. There were a larger portion of women vs. men who met criteria for revascularization $77 \%$ [confidence interval (CI), $71 \%$ to $84 \%$ ] vs $72 \%$ [CI, $65 \%$ to $80 \%$ ]). There were no significant differences between African-American, Hispanic, and Caucasian patients (72\% [CI, 65\% to 80\%]; 67\% [CI, $54 \%$ to $76 \%$ ]; $75 \%$ [CI, $72 \%$ to $78 \%$ ]). The uninsured did have a lower rate of revascularization, 
but this was not significant compared to private or government insurances. There was a significant difference between hospitals that had on-site vs. off-site revascularization facilities regarding patients receiving revascularization $87 \%$ vs $21 \%$. The rates for hospitals with off-site facilities were lower compared to those with on-site facilities. Rates were lower in municipal hospitals than private hospitals $(61 \%$ vs $75 \%)(\mathrm{p}=0.02)$. The review concluded that patients in New York City receive cardiac revascularization when needed without regard to sex, ethnicity or ability to pay. However, there were patients who needed a procedure and did not get one. More often, if someone was treated at a hospital that did not have the capability of performing the procedure onsite and the patient did not have insurance, he/she was more likely not to receive the needed procedure. The strengths of the study were: a clearly focused question, comparable groups, clearly defined outcomes, and CIs were used. Weaknesses of the study included: selfreported ethnicity may have produced bias, off-site hospital sample size was low, and the study may not have identified patients that refused the recommended procedures.

Goldberg et al. (2001) used a cohort study design to determine whether an interaction between sex and age affects mortality and morbidity two years following a myocardial infarction. The results of the study found that women at age sixty and younger had a significantly higher mortality rate than men (28.9\% vs $19.6 \%$; hazard ratio for women compared with men, 1.47 [95\% CI, 1.35 to 1.61$])$. However, after age sixty, the rate of mortality in women compared to men decreased with increasing age. The oldest men actually had a higher rate of mortality than women $(\mathrm{P}=0.009)$. The strengths of the study were: a clearly focused question, comparable groups, use of CIs, and identified confounders. One limitation in the study was the lack of available information on reproductive history, smoking status, menopausal status, or behavior and psychological status. 
Bugiardini et al. (2011) completed a retrospective cohort study of the Canadian Registry of ACS I and II that included 6,558 patients who had a final diagnosis of ACS. The aim of the review was to determine if there were differences between men $(4,471)$ and women $(2,087)$ in the use of cardiovascular medication for ACS. Women were found not to be given evidencebased therapies as often when compared to men. This was associated with age, consequences of disease, and physician assessment. Women were less likely to receive beta-blockers $(75.76 \%$ vs 79.24\%; $\mathrm{p}<0.01)$, lipid-modifying agents (56.3 vs 65.44\%; $\mathrm{p}<0.0001)$ and ACE inhibitors $(55.52 \%$ vs $59.99 \%$; $\mathrm{p}<0.01)$. Women were also less likely to be referred for cardiac catheterization (41.9\% vs 49.6\%; $<<0.001)$. Physician's decision not to utilize ACE inhibitors and lipid modifying agents were linked to the decision not to utilize cardiac catheterization in women. Women's age and risk stratification using the Killip class were identified as reasons not to use beta blockers. The conclusion of the review suggested that despite a women's age, Killip class, and physician's assessment giving rationale that could prohibit the use of some medications such as beta-blockers, there still was no significant reason to withhold evidencebased therapies in women such as lipid modifying agents and ACE inhibitors. Strengths of the study were: appropriate and clearly focused question, comparable groups, clearly defined outcomes, and CIs.Weaknesses of the study were adherence to evidence based practice (EBP) was not used throughout the study period, and the relative contraindications to medications were not evaluated.

Chaitman et al. (1994) conducted a retrospective cohort study with 872 middle-aged patients' ages $45-65$ years (47\% women vs $53 \%$ men) that were referred to outpatient testing centers. The aim of the study was to determine if gender-based differences exist in the post stress test management and clinical outcomes of patients with clinically suspected CAD. The patients 
in the study had undergone a stress electrocardiographic or myocardial perfusion evaluation. The study found a significant difference between men and women in the post stress evaluation. First, women were less likely to have had any further evaluations following a positive stress test than men $(38.0 \%$ vs $62.3 \%)$ ( $\mathrm{p}=0.002)$. Second, coronary revascularization was performed more frequently in men than women $(4.9 \%$ [22 of 449] vs $2 \%$ [8 of 391]) $(\mathrm{p}=0.03)$. Finally, men died less frequently from an MI in a two-year post-stress test follow-up than women, $2.4 \%$ [11 of 449] to $6.9 \%$ [27 of 391]) ( $\mathrm{p}=0.002)$. The study concluded that following non-invasive stress tests, with similar rates of angina, cardiac risk factors, and positive stress tests women were less likely to receive additional testing or interventions and died more frequently than men in a twoyear follow-up evaluation. The strengths of the study were: a clearly focused question, comparable groups, defined confounders, clearly defined outcomes, and recruitment of a large heterogeneous group. Weaknesses were no reference to blinding and data collected from one facility limited generalizability.

Curtis et al. (2002) completed a cohort study with a prospective data collection of 21,816 patients. The aim of the study was to determine if there was a difference in the rate of percutaneous interventions (PCIs) or cardiac bypass graft (CABG) surgeries following cardiac catheterization between women and men. The study included 6,407 women and 15,409 men. The study found that women were less likely than men to undergo PCI or CABG surgery within one year from catheterization $(40.2 \%$ [2,575 of 6,407$]$ vs $55.1 \%[8,488$ of 15,409$])(\mathrm{p}<0.001)$. Relatively speaking, women were $33 \%$ less likely to have any revascularization procedure, $23 \%$ less likely to have PCI, and $46 \%$ less likely to have CABG surgery than men. However, the study does go on to include an adjusted rate, which compared men that had revascularization to the men that did not and compared women that had revascularization to women that did not and 
found that the actual statistical rates for men and women were equivalent for revascularization.

The unadjusted relative risk was 0.67 (95\% CI, 0.65 to 0.71 ) for the end point of any revascularization in women relative to men. At partial adjustment, the relative risk increased to 0.69 (95\% CI, 0.66 to 0.72 ) and at full adjustment increased to 0.98 (95\% CI, 0.94 to 1.03 ). The extent of CAD accounted for almost the entire relative risk adjustment model. Strengths of the study were: CIs were used, the groups were comparable, and confounders were identified. Weaknesses of the study were no clearly focused question, and interpreting the results of the study was difficult and could be easily misinterpreted.

Barrett-Connor et al. (2003) completed a prospective cohort study of a clinical trial of 2,763 postmenopausal women with known CAD from the Heart and Estrogen/Progesterone Replacement Study. The aim of the study was to determine the use of secondary prevention treatment in women assessing risk factors and event rates. The study found that the annual rate of women who had ACS with no risk factors was $1.3 \%$ (95\% CI, $0.7 \%$ to $2.5 \%$ ) and women with five or more risk factors had a "six fold increase" in ACS to 8.7\% (CI, 7.1\% to 10.8\%). Women with more than 2-3 risk factors were less likely to be treated with aspirin $(\mathrm{p}<0.001)$ and lipidlowering medications $(\mathrm{p}=0.006)$. Additionally, only $33 \%$ were given beta blockers, and $18 \%$ given ACE inhibitors. The study concluded that despite the fact that women were at a high risk for $\mathrm{MI}$ or death from $\mathrm{CAD}$, secondary prevention medications, even in the most high risk patients, were underutilized. Strengths of the study were: a clearly focused question, comparative groups, clearly defined outcomes, CIs, and blinding. Weaknesses were that voluntary participants were used in a secondary prevention trial thus the sample may differ from the general population of women with CAD limiting generalizability. 
Buring et al. (2008) completed a prospective cohort study of 38,987 women from a double-blinded randomized clinical trial of a Women's Health Study. The aim of the study was to determine if the combined association of physical activity and body mass index (BMI) affected Coronary Heart Disease (CHD) in women over a 10.9 mean year period. The participants' inclusion criteria included being free of CAD, diabetes, and cancer at baseline. Only $34 \%$ were considered physically active at baseline. Of the participants, $51 \%$ were considered normal weight, $31 \%$ overweight and $18 \%$ obese at baseline. The study found that 948 women developed CAD at a mean of 10.9 years. As BMI increased, adjusting for potential co-founders, the risk of CAD increased $(\mathrm{p}<0.001)$. The study also showed that BMI and physical activity were independent predictors of CAD. Women whose BMI increased and who were inactive had a higher incidence of CAD compared to normal weight inactive vs. overweight inactive $(\mathrm{p}<0.001)$, and overweight inactive vs. obese inactive $(\mathrm{p}<0.005)$. There was a higher incidence of CAD in normal weight vs. overweight or obese women ( $\mathrm{p}=0.005$ and $\mathrm{p}=0.001$ respectively). However, there was no significant difference between the overweight and obese groups developing CAD. The study concluded that the more overweight or obese a woman is and her lack of physical activity does increase her risk of developing CAD. The strengths of the study were: comparable groups, clear outcomes, and identified cofounders. The weaknesses were: no clear question was used, self-reported physical activity data was used, and occupational physical activity was not reported.

Clark, Finlay, Hartling, McAlister, and Vandermeer (2005) completed a meta-analysis of 63 randomized trials that included 21,295 patients with CAD. The aim of the study was to determine the effectiveness of secondary cardiac prevention with and without exercise components at 12 and 24 months after the intervention. The study examined the effect of 
reducing MIs and death by providing three different types of interventions: education or counseling with a structured exercise program, exercise program with no education or counseling, and education or counseling without exercise. The study found no significant effect at 12 months from any of the secondary prevention programs (risk ratio of 0.97 [0.82 to 1.14]). However, there was a significant difference in the reduction in MI and death at 24 month (risk ratio 0.53 (CI, 0.35 to 0.81 ). There was no significant difference in the use of secondary prevention programs: education or counseling with exercise for death, 0.88 (CI, 0.74 to 1.04), for MI 0.62 (CI, 0.44 to 0.87 ), education or counseling without exercise for death, 0.87 (CI, 0.76 to 0.99), for MI 0.86 (CI, 0.72 to 1.03), exercise alone for death, 0.72 (CI, 0.5 to 0.95 ), or for MI, 0.76 (CI, 0.57 to 1.01 ). Despite the wide variety of secondary prevention programs, all programs seemed to decrease the incidence of death and MI with no significant differences between them. Strengths were: a clearly focused question, similar treatment and control groups, and relevant outcomes measured in a standard and reliable way. Significant limitations in the study were lack of blinding, and insufficient details on randomization or whether allocation of concealment was achieved in most trials.

Brogan et al. (2006) completed a retrospective observational analysis that compared a total of 86,895 patients (37,345 Medicaid and 59,550 Medicare) to the treatment of similarly aged patients with either HMO or private insurance coverage. The aim of the study was to compare the treatment of non-STEMI ACS patterns that had different insurances. The study used current ACS guidelines established by the American College of Cardiology (ACC) and American Heart Association (AHA) to determine compliance. The study found that Medicaid patients were less likely to receive medication and invasive cardiac procedures compared to patients with HMO and private insurance. Medicaid patients also had an increase in mortality 
(2.9\% vs. $1.2 \%$; adjusted odds ratio, $1.33 ; 95 \%$ CI, 1.08 to 1.63 ). However, among Medicare, private insurance, and HMO patients, there were no significant differences in the rate of medication administration or invasive procedures. Mortality rates were also similar (6.2\% vs. $5.6 \%$; adjusted odds ratio, $1.08 ; 95 \%$ CI, 0.99 to 1.18$)$. The study concluded that Medicaid patients were less likely to have evidenced-based treatment for ACS resulting in a higher rate of mortality than patients with Medicare, private insurance, and HMO. Strengths of the study were: questions were clearly focused, CIs were used, comparisons were made between participants, comparative populations were used, and confounders were identified. A limitation of the study was that the investigators were unable to determine if Medicaid and Medicare patients did not receive invasive interventions at the same rate as $\mathrm{HMO}$ and private insurance because the procedures were underutilized in Medicaid/Medicare insurances or if the procedures were over utilized in HMO and private insurance for monetary gain.

Akhter et al. (2009) completed a descriptive retrospective cohort study of 199,690 patients (131,664 men and 68,026 women) who presented at the hospital with ACS. The aim of the study was to determine if there was a significant difference between men and women in postintervention outcomes. Of the population, 55,691 presented with unstable angina or non-st elevated myocardial infarction (STEMI), 12,335 presented with STEMI. The review found that women were more likely to present with angina or non-STEMI than men (82\% vs $77 \%$; $\mathrm{p}<0.01)$. Women were also more likely to have had previous congestive heart failure (CHF) or to have presented with CHF symptoms than men $(\mathrm{p}<0.01)$. Women were less likely to be started on aspirin or glycoprotein IIb/IIIa inhibitors (antiplatelet agents) and less likely to be discharged on aspirin and lipid lowering medications. The study concluded that even though women were less likely to receive certain medications than men, the rate of complications following 
revascularization was higher in women, more specifically bleeding. However, women were actually less likely than men to have stent thrombosis $(0.43 \%$ vs. $0.57 \%, \mathrm{p}=0.0003)$. The rate of in hospital mortality was not significantly different (OR 0.97, 95\% CI, 0.88 to $1.07, \mathrm{p}=0.52$ ). The strengths of the study were a clearly appropriate question, the groups were comparable, the outcomes were clearly defined, and CIs were provided. Limitations were not discussed.

Arslanian-Engoren (2004) completed a prospective descriptive cohort study of 13 triage nurses and 108 patients. The aim of the study was to determine if triage nurses' initial decisions influenced the admission or discharge diagnosis of patients with ACS. The study found that of the $47 \%$ of patients that the triage nurse thought had ACS, only $68 \%$ received an admission diagnosis of ACS. Forty-four percent of patients that the triage nurse determined did not have ACS were actually diagnosed with ACS ( $\mathrm{p}=0.09)$. The significant predictors of ACS by the triage nurse were patient history of CAD, MI, chest pain, and smoking. Patients' sex, race and age did not predict ACS. Of the 17 men and 19 women that the triage nurse thought might be diagnosed with ACS, there were no significant sex differences in the likelihood scores of ACS (70 \pm 24 vs. $76 \pm 26 ; p=0.49)$. The study concluded that the triage nurse did not make a significant difference in the ability to predict ACS in patients. Strengths of the study included: an appropriate clearly focused question, comparable groups, and clearly defined outcomes. Limitations of the study were that there was a reliance on a convenience sample of ED nurses that worked in the mid-west, and there were a small number of participants.

Gao et al. (1997) completed a retrospective chart review of 2,409 patients in 37 hospitals. The aim of the study was to determine why patients who have had an MI delayed coming to the hospital. The study found that $40 \%$ of the patients who delayed coming to the hospital for more than six hours were more likely to have advanced age and be female. The greatest time delays 
were from $6 \mathrm{pm}$ to $6 \mathrm{am}$ with midnight to 5:59 am being the greatest risk for a delay (adjusted odds ratio (3.64 [95\% CI, 2.55 to 5.21$])$. Only $42 \%$ of the patients used emergency medical services for transportation to the hospital. The study concluded that patients who have an MI often delay seeking medical attention. Factors that affected the decision to seek medical attention were advanced age, being female, attempts to self-treat, extended decision process, and underuse of emergency medical services. Strengths were: a clearly focused question, comparable groups, CIs, clearly defined outcomes, and identified confounders. Limitations included: relying on retrospective chart review for all data, no access to the patient's provider to obtain specific information that was not included in the patient's chart, and recruitment limited to one state.

Baker et al. (2009) conducted a randomized clinical trial of 3,522 participants with diagnosed CAD. The aim of the study was to determine if an intervention conducted specifically for patients with CAD would reduce pre-hospital delay times. The study found that post intervention there were no significant differences between the experimental and control groups 2.20 vs. 2.25 hours respectively. There was a significant difference in emergency medical services used when symptom occurred within the first six hours $(\mathrm{p}=0.036)$. The use of aspirin with onset of symptoms was increased in the experimental group compared to the control group ( $22.3 \%$ vs. $10.1 \% ; \mathrm{p}=0.02)$. Finally, the intervention did not produce a significant difference in the utilization of the emergency department between the experimental and control groups (14.6\% vs $17.5 \%$ ). The trial concluded that there was no significant difference in delays in presenting to the hospital in patients with ACS who developed chest pain. Strengths of the study included: it was a blinded and randomized study, it was conducted over a two year period, written informed consent was provided, similar treatment and control groups were used, and study methods were well described. Weakness of the study were that there were no clearly focused questions and that 
the length of the intervention should have been longer as the participants were elderly and may take a longer period of time to understand information.

\section{Synthesis}

The evidence collected through the evaluation of 18 documents including one systematic review (Adomaityte et al., 2008), four randomized control trials (Afzal et al., 2009; Aiken et al., 2009; Clark et al., 2005; Davidson et al., 2009); eleven cohort studies (Akhter et al., 2009; Arslanian-Engoren, 2004; Barrett-Connor et al., 2003; Bell et al., 1999; Bugiardini et al., 2011; Buring et al., 2008; Chaitman et al., 1994; Gao et al., 1997; Curtis et al., 2002; Goldberg et al., 2001; Krumholz et al., 2002); one case control study (Brogan et al., 2006); and two Clinical Practice Guidelines (Adams et al., 2011; Ardissino et al., 2007); support the need for an intervention to decrease delays in the care and treatment of women with ACS. Based on the review of the literature (ROL), these studies support the findings that women are treated less urgently than men and that the delay in treatment increases the morbidity and mortality of women. Homogeneity was evident in the majority of studies. The data also suggest there is a decrease in mortality and morbidity across the life span, especially with adult women less than 60 years of age. Confounding variables were determined in most of the studies to include age, sex, and ethnicity. Not all studies addressed similar methods between the sites in gathering the data. The research suggests that interventions aimed at the patients do not have a significant outcome. Gaps in the literature show that future studies on interventions to decrease bias among providers needs to be conducted, which supports the proposed intervention. 


\section{PICO}

Will an educational program on atypical signs and symptoms of acute coronary syndrome in women for emergency department staff at a local hospital in Southern West Virginia increase knowledge? Will the staff apply the knowledge to improve the CORE measures: EKG less than 10 minutes, door to thrombolytic administration less than 30 minutes and aspirin administration in the ED?

\section{Congruence of Organizations Strategic Plan to Project}

The mission statement of Princeton Community Hospital is that "Princeton Community Hospital will lead in building a health care system that provides a broad range of health care services which improve the health status of individuals in defined geographic regions. We will emphasize high quality, low cost and predictable outcomes for all our services" (PCH website: NA, 2012). The intervention that is planned is aimed at improving the health status of individuals. Working with the ED nurse manager, medical director and vice president (VP) of risk management, the investigator has developed an educational program for providers to identify the atypical signs and symptoms of acute coronary syndrome with which women present in the ED. The goal can be attained through increasing the knowledge of the providers to increase compliance with the CORE measures in the ED (the time the patient enters the hospital to $\mathrm{EKG}$ of less than 10 minutes, the time the patient enters the hospital to thrombolysis of less than 30 minutes, and aspirin administration in the ED).

\section{Project Objectives}

1- $\quad$ To increase provider knowledge about the atypical signs and symptoms of ACS in women presenting to the ED. This outcome will be measured following the completion of 
an educational intervention by comparison of pre and post-test scores using a paired sample t-test.

a. Delays in the treatment of women with ACS

b. Atypical signs and symptoms of ACS with which women present to the ED

c. Measurement of CORE values

d. Understanding of the mortality and morbidity of women with ACS

2- $\quad$ To enable providers to apply the knowledge of the atypical signs and symptoms of ACS with which women present to the ED as measured by an increase in CORE measures from base line to 3 month post intervention as measured by a retrospective chart review using an descriptive statistics.
a. Door to EKG less than 10 minutes
b. Door to thrombolysis less than 30 minutes
c. Aspirin administration in the ED 


\section{CHAPTER III - METHODOLOGY}

\section{Project Design}

The capstone educational intervention was undertaken in the fall of 2012 at Princeton Community Hospital $(\mathrm{PCH})$. This capstone project was constructed with a one group pretest posttest quasi-experimental design with a convenience sample of ED providers. Prior to and following a onetime intervention on the atypical signs and symptoms of ACS in women, provider knowledge was evaluated. A retrospective chart review was used to measure the application of this knowledge to improvement in CORE measures three months post intervention.

Direct stakeholders were the providers that participated in the intervention: 41 registered nurses, 7 advanced practice clinicians, and 6 physicians. The indirect stakeholders were the many women who presented to the ED with atypical signs and symptoms of ACS and the hospital through meeting CORE measures set forth by CMS. Additionally, the local community, county, and state would benefit from decreasing overall morbidity and mortality in women with ACS.

\section{The Intervention}

1- Baseline data from three months prior to the intervention was collected on CORE measure: door to EKG, door to thrombolytic administration, and aspirin administration in the ED.

2- Presentation of the intervention was held on multiple dates and times. Healthy snacks and drinks were served. Once participants arrived, they were given a pre-test, which was completed in approximately 15 minute. A power point presentation included reasons for delays in women with ACS seeking treatment, atypical signs and symptoms of ACS with which women present to the ED, CMS CORE measures, and mortality and morbidity 
statistics on women with ACS. The power point presentation lasted approximately 30 minutes. There was a short $15-20$ minute question and answer period followed by the post-test. Allowing 15 minutes to complete the post-test the intervention was completed.

3- For the three months following the intervention, the same CORE measures was collected and compared with the baseline measure to see if there was an improvement.

4- Results of the pre and post-test, baseline data, and post intervention data were shared with the participants.

5- The director of education was given the intervention in its entirety so that $\mathrm{PCH}$ can continue the education through yearly in-services and orientation programs for new hires in the ED.

\section{Budget}

The cost of the project was difficult to actually determine as the largest cost was the salaries of the participants. However, $\mathrm{PCH}$ and Team Health have agreed to be responsible for their respective employees' salaries thus they participated in the intervention at no cost to the investigator. There was no cost for classroom space, copies of pre and post-tests, and audiovisual equipment. The other cost was the time the investigator spent gathering pre and post data, implementing the intervention, providing the food, and disseminating the data collected. The investigator's time was free as well.

There were 41 registered nurses, 6 physicians, and 7 advanced practice clinicians. The investigator estimated the cost of nursing salaries to be $\$ 1,230.00$ dollars. The investigator arrived at this figure by taking an average of $\$ 20.00$ dollars per hour for 41 nurse's times one and a half hours. The investigator estimated the cost of the allied health clinician's (AHC) salaries to be $\$ 525.00$ dollars. The investigator arrived at this figure by allowing $\$ 50.00$ dollars per hour 
times 7 AHC for one and a half hours. The investigator estimated the physician's salaries to be $\$ 1,075.00$ dollar. The investigator arrived at this figure by allowing $\$ 125.00$ dollars per hour for 8 physicians time one and a half hours. The total cost of salaries is projected to be $\$ 2,830.00$ dollars.

The investigator has estimated the cost of the operating budget to be as follows: advertising \$250.00 dollars, AV equipment rental \$500.00 dollars, pre and post-test copies $\$ 250.00$ dollars, Classroom space rent $\$ 500.00$ dollars, and food $\$ 500.00$ dollars. The total cost of the operating budget is projected to be $\$ 2,000.00$ dollars.

The total cost of the intervention was projected to cost $\$ 4,830.00$ dollars. The cost of the intervention was paid by $\mathrm{PCH}$ and Team Health. The total projected budget can be found in

\section{Appendix B.}

\section{Key Site Support}

Kim Poe, RN, BSN, Nurse Manager ED/ICU/CCU/Employee Health, Dr. Michael Mills, DO, Richard Puckett RN, BSN, Vice President are the key supporters that determined that the project could be implemented at PCH. Each key supporter agreed to allow the intervention and pledged to help in any way possible. Copy supplies and allowing staff to participate during work hours was granted along with the use of any audio-visual aids that were needed. See Appendix $C$ for support letter.

\section{Conclusion}

In conclusion, it is clear that women are not treated as emergently or as in-depth as men. Women are less likely to be urgently diagnosed with acute coronary syndrome, receive thrombolytic therapy, or undergo percutaneous coronary intervention than men (Afzal et al., 2009; Adomaityte, Khalid, Messineo, Papadakos, \& Qayyum 2008) Therefore, an intervention to 
educate the nurses, physicians, and allied health clinicians was completed in the fall 2012 at a rural hospital in southern West Virginia.

The goal of this intervention was to increase the knowledge of providers and nurses on the atypical signs and symptoms of acute coronary syndrome in women who presented to the ED. Through knowledge gained, CORE measure set by CMS could increase. Through the knowledge gained physicians and allied health clinicians could emergently treat women with ACS, reducing mortality and morbidity. 


\section{CHAPTER IV - RESULTS}

\section{Demographics}

The total number of ED staff that was potentially able to participate in the intervention was 75. Of that total number, $54(72 \%)$ participated in the recognition of acute coronary syndrome (ACS) in women intervention and completed both the pre and post-test. The other (28\%) were either on vacation or were not scheduled during the intervention time frame. All of the potential participants approached agreed.

The majority $37(68.5 \%)$ of the participants in the intervention were female and registered nurses. There were 4 (7.4\%) male registered nurses, $3(5.6 \%)$ female physician assistants, 2 (3.7\%) female nurse practitioners, $3(5.6 \%)$ female physicians, $3(5.6 \%)$ male physicians, and $1(1.9 \%)$ male nurse practitioner and $1(1.9 \%)$ male physician's assistant. The majority of all participants were between the ages of $41-50$ years $(35.2 \%)$. The rest were between age $18-30$ years $(16.7 \%), 31-40$ years $(27.8 \%), 51-60$ years $(13 \%)$ and greater than 60 years $(7.3 \%)$ (Table III).

\section{Provider Knowledge}

Objective 1: Increase provider knowledge about the atypical signs and symptoms of ACS of women presenting to the ED.

The pre and post-test were completed by all participants on the day they received the intervention. There were 20 questions that each participant was asked to complete. The pre-test was exactly the same as the post-test. A paired sample t-test was used to compare the difference between the pre and post-test. The pre-test had a mean score of 70.0 and the post-test had a mean score of 90.5 ( $\mathrm{p}<0.001)$. See Tables IV. 


\section{Core Value demographics}

The second objective was to increase provider's application of the knowledge of the atypical signs and symptoms of ACS with which women present to the ED as measured by an increase in CORE measures from baseline to 3 months post intervention as measured by a retrospective chart review. An increase of five percent from pre to post intervention of all COR measures was the benchmark set to prove success in the intervention.

The inclusion criteria for participants were; a patient registered in the ED, a diagnosis of chest pain, myocardial infarction, STEMI, non-STEMI, angina, non-cardiac chest pain, at least age 18, chest wall pain, and ACS. Non-cardiac chest pain and chest wall pain were all included, as the patient presented to the ED with a chief complaint of chest pain.

There were 23,385 potential patients, 1,182 met criteria for inclusion. Of the number who met criteria, there were 679 females and 503 males. For the age breakdown of participants see Table V.

During the six month evaluation time, $63 \%$ of men and $26 \%$ of women had an EKG in less than 10 minutes from arrival to the ED. In the pre-intervention time frame, 96/344 (27\%) of the women and 100/254 (39.3\%) of the men had an EKG in less than 10 minutes from arrival in the ED. In the post evaluation time frame, 81/335 (24\%) of the women and 82/249 (32.9\%) or the men had an EKG in less than 10 minutes from arrival to the ED. This was an overall decrease in 3\% of women and $6.4 \%$ decrease in men who received EKG's in less than 10 minutes from arriving in the ED. See Table VI.

There was $33 / 1182$ or $0.02 \%$ of all patients who met criteria for evaluation presented to the ED with a STEMI. Of those pts who had a STEMI, a total of 13/33 (39\%) were given TNKase in less than 30 minutes from the time they arrived in the ED over the pre and post 
intervention period. There were 12 women who had a STEMI and 6/12 (50\%) received TNKase. There were 21 males who had a STEMI and 8/21 (38.1\%) received TNKase. There were 7 women that had a STEMI pre-intervention with 2/7 (28\%) receiving TNKase in less than 30 minutes from arrival to the ED. There were 10 males that had a STEMI pre-intervention with 5/10 (50\%) receiving TNKase in less than 30 minutes from arrival to the ED. In the postintervention period, there were 5 women who presented with STEMI and 4/5 (80\%) of them received TNKase within 30 minutes from arrival to the ED. In the post-intervention period, there were 12 males who presented with STEMI and 3/12 (25\%) of them received TNKase within 30 minutes from arrival to the ED. This was an overall increase of $52 \%$ of women who received TNKase in less than 30 minutes from the time they arrived in the ED, while men who received TNKase in less than 30 minutes dropped by $25 \%$. See Table VII.

There were $871 / 1182(73 \%)$ of all pts who met criteria for evaluation and were given ASA in the ED during the 6 month evaluation period. Of the total number of participants that were eligible for ASA, 679 were female and 503 were male. There were 250/344 (72.6\%) of women and 186/254 (73.2\%) male who received ASA in the ED during the pre-intervention time frame. There were $246 / 335(73.4 \%)$ of women and 189/249 (75.9\%) of males who received ASA during the post-intervention time frame. There was a $0.8 \%$ increase in the number of women who received ASA from the pre-intervention, while the males had a $2.7 \%$ increase in ASA administration in the ED. See Table VIII.

\section{Program Evaluations}

The intervention evaluations were completed after the three month post-intervention was completed. There were four questions in the post-intervention evaluation. Each participant was 
given the evaluation to complete and then it was placed in an envelope so that the participants would remain anonymous. All 54 participants completed the post evaluation.

Question one asked: Was the intervention useful? 100\% of the participants answered yes to this question.

Question two: Have you implemented what you learned in the intervention into your practice? $100 \%$ of the participations answered yes to this question.

Question three: Did you learn at least one new atypical sign and symptom that women present to the Ed with when experiencing ACS? $100 \%$ of the participants answered yes to this question. Question four: Would you suggest this intervention be repeated in the future? $100 \%$ of participants answered yes to this question. 


\section{CHAPTER V - SUMMARY, DISCUSSION, IMPLICATIONS}

\section{Congruence with theoretical framework}

The theoretical framework designed by Everett M. Rogers', Diffusion of Innovation theory, was chosen to help guide the project. The first part of Roger's theory guides stages one through five of the innovation. The participants were guided through the first three stages by the investigator publicizing the intervention through the placement of flyers in the ED and by communicating in routine meetings when the intervention was going to take place. This publicity was successful in recruiting 54 participants for the intervention. The last two stages were up to each individual participant, which included his or her decision to implement what was discussed or reject the information provided. In an effort to increase the number of participants that would adopt the information that was provided, the investigator used evidence based practices to develop the intervention.

The second part of Roger's theory identifies participants as being in five stages of innovation. This part of the theory was very helpful as the investigator was able to find the innovators and early adopters to help support the intervention so that they and the early majority could help convince the late majority and laggards to adopt the intervention that was presented.

\section{Discussion}

Women with ACS present to the ED with atypical signs and symptoms more often than men do as previously discussed. This intervention was aimed at increasing the knowledge of the providers in the ED on atypical signs of ACS in women and evaluating the application of knowledge through an improvement in the CORE measures as set by CMS in the emergency department. There were three CORE measures that were assessed. The measures were assessed three months before and three months after the intervention. During the intervention, there were 
only $72 \%$ of the providers who participated as the other $23 \%$ were either on vacation or did not work during the intervention. This is significant as the outcomes that were measured may have been improved more with $100 \%$ participation. No participant that was approached declined to participate.

\section{Provider Knowledge}

There was a significant increase $(30 \%)$ in provider knowledge from the pre-test to the post-test. In the review of the literature, Aitken et al., (2009) supported this intervention as providers need to be educated on the atypical signs and symptoms with which women present to the ED to decrease bias in the treatment between men and women. Furthermore, in the review of the literature, Baker et al. (2009) and Gao et al. (1997) supports the need to decrease the delays in the treatment of women with ACS. This intervention proved to increase the knowledge base of the providers as evidenced in an increase in test scores and CORE measure attainment.

\section{CORE Measure: EKG}

Of the participants that met the inclusion criteria, only $30 \%$ received an EKG in less than 10 minutes. Although the percentage for women decreased (27.9\% vs $24 \%)$, there were other factors that could have influenced these findings. Although time to EKG dropped $3.8 \%$ in women, it dropped $6.4 \%$ in men. This may have indicated an overall delay post intervention. Even though this had decreased, there were other factors that influenced this time line. Other influences were, the time it took the unit secretary to page cardio-pulmonary that an EKG was needed and the amount of time it took the cardio-pulmonary person to respond to the ED.

\section{CORE Measure: TNKase}

There were 33 patients that met criteria for TNKase administration. Of those, there was (39\%) that received TNKase in less than 30 minutes. Only six of the twelve women who met 
criteria for TNKase actually received it in less than 30 minutes. However, from pre-intervention to post-intervention, there was an $52 \%$ increase in the administration of TNKase to women in the ED in less than 30 minutes from their arrival. This number can also be affected by the length of time from the onset of symptoms of ACS until the time the patient actually presented to the ED. Another possible reason for not receiving TNKase is if the time from onset of symptoms to the time they are in the cardiac cath lab is less than 90 minutes, the patient would not be given TNKase. This is less likely as the time of transport is generally longer than the 90 minute time line from the facility where the intervention had taken place to the nearest cath lab.

\section{CORE Measure: Aspirin}

All participants that met inclusion criteria met criteria for ASA administration. Of the participants that met inclusion criteria only 871 (73\%) actually received ASA while in the ED. From pre to post intervention there was a slight increase from 72.67 to 73.43 . Even though all participants met criteria for ASA administration, not all patients were able to receive ASA due to issues such as allergies and contraindications associated with other potential chief complaints such as some type of bleeding like hemorrhagic stroke. These potential reasons for not receiving ASA were thought to be very low and do not create bias in the results.

\section{Recommendations}

This intervention has proven to make a positive impact in the recognition of atypical signs and symptoms with which women who presented to the ED. It is encouraging to see the increase in early administration of TNKase in women diagnosed with a STEMI in the ED. The stable number of women receiving an ASA in the ED is also hopeful as there was no decline. The decrease in women receiving an EKG in 10 minutes or less was troubling but also encouraging. This investigator now believes that including others such as unit secretaries and 
cardio-pulmonary staff in similar interventions are needed to improve the number of women receiving an EKG within 10 minute. Finally, such interventions, as the one provided are needed all over the world to reduce the unnecessary poor outcomes and premature deaths of women. The efforts such as this intervention should be replicated in all emergent care centers around the world. By increasing the knowledge of providers and ancillary staff of atypical signs and symptoms of ACS in women, women receive better and more emergent care in emergency departments, which may lead to decrease mortality and morbidity. The hospital has agreed to implement this project in future educational sessions with new ED providers.

\section{Limitations}

There were many limitations of this intervention. The sample was a convenience sample and the size was small. The study was conducted in a rural hospital in West Virginia thus the results are not generalizable. The instruments were constructed by the investigator. Only $72 \%$ of the potential participants were able to attend the intervention, and this may have affected the application of knowledge. The most limiting factor was that the investigator was set to use data collected by the facilities audit department. However, when reviewing the data that was collected, the investigator found that the data was not what was needed to evaluate the application of the intervention, and he had to process a large amount of data needed to appropriately evaluate the application of the intervention CORE measure himself. Another major limiting factor that is believed to impact this intervention is not including unit secretaries and cardio-pulmonary staff in the intervention. 


\section{Conclusion}

The lack of knowledge of providers about the atypical signs and symptoms with which women present to the ED when experiencing ACS is staggering. The intervention conducted in the ED at a local hospital in Southern West Virginia proved to be successful in more than one way. There was a $30 \%$ increase in knowledge for the provider's pre to post test. The application of this knowledge was seen in a 52\% increase in TNKase administration in women while administration of TNKase in men decreased 32\%. Although time to EKG dropped 3.8\% in women, it dropped $6.4 \%$ in men. The inclusion of ancillary staff responsible for the EKG in the intervention may have improved the time to EKG data. Aspirin administration also improved slightly $0.8 \%$ in women, while men had a higher increase of $2.7 \%$. The intervention proved feasible in a busy emergency department with the financial support of the administration. Further replication with the inclusion of the ancillary personnel is warranted. 


\section{References}

Adams, C.D., Anderson, J. L., Bridges, C. R., Casey, D. E., Ettinger, S. M., Fesmire, F. M., Zidar, J. P. (2011) ACCF/AHA focused update of the guidelines for the management of patients with unstable angina/non-st-elevation myocardial infarction (updating the 2007 guideline). Journal of the American College of Cardiology 57(19) 1924-1932 \& 19401948

Adomaityte, J., Khalid, M. R., Messineo, F. C., Papadakos, S. P., \& Qayyum, R. (2008). Systematic review: Comparing routine and selective invasive strategies for the acute coronary syndrome. Annals of Internal Medicine, 148, 186-196.

Afzal, R., Avezum, A., Bassand, J. P., Boden, W. E., Chrolavicius, S., Col, J.,...Zhu, J. (2009). Early versus delayed invasive intervention in acute coronary syndromes. The New England Journal of Medicine, 360(21), 2165-2175.

Aiken, L. M., Buckley, T., Doreing, L. V., Dracup, K., Marshall, A., McKinley, S.,...Riegel, B. (2009). The effects of a short one-on-one nursing intervention on knowledge, attitudes, and beliefs related to response to acute coronary syndrome in people with coronary heart disease: A randomized controlled trial. International Journal of Nursing Studies, 46(8), 1037-1046.

Akhter, N., Milford-Beland, S., Kao, J., Piana, R. N., Roe, M. T., \& Shroff, A. (2009). Gender difference among patients with acute coronary syndromes undergoing percutaneous coronary intervention in american college of cardiology-national cardiovascular data registry (ACC-NCDR). American Heart Journal, 157, 141-148.

American Heart Association (2010). Heart disease and stroke statistics. Retrieved from http://circ.ahajournals.org/content/123/4/e18.full.pdf 
Appraisal of guidelines for research and evaluation (2001). The AGREE Collaboration. Retrieved from http://www.agreecollaboration.org

Ardissino, D., Bassand, J. P., Budaj, A., Fernandez-Aviles, F, Fox, K. A., Ham, C. W.,.Wijns, W. (2007). Guidelines for the diagnosis and treatment of non-st-segment elevation acute coronary syndrome.European Heart Journal, 28, 1598-1660.

Arnsdorf, M. F., Black, H. R., Cooper-Dehoff, R. M., Gulati, M., Handberg, E. M., Johnson, B. D.,...Zineh, I. (2009). Adverse cardiovascular outcomes in women with non-obstructive coronary artery disease.Archives of Internal Medicine, 169(9), 843-855.

Arslanian-Engoren, C. (2004). Do emergency nurses' triage decisions predict differences in admission or discharge diagnoses for acute coronary syndromes? Journal of Cardiovascular Nursing, 19(4), 280-286.

Baker, H., Davidson, P., Doering, L. V., McKinley, S., Meischke, H., Moser, D. K.,...Riegal, B. (2009). A randomized clinical trial to reduce patient pre-hospital delay to treatment in acute coronary syndrome.Circulation Cardiovascular Quality Outcomes, 2(6), 524-532.

Barrett-Connor, E., Blumenthal, R., Furberg, C. D., Hully, S., Ireland, C. C., Khan, S.

S.,...Varosy, P. D. (2003). Risk factors and secondary prevention in women with heart disease: the heart and estrogen/progesterone replacement study. Annals of Internal Medicine, 138, 81-89.

Bell, R., Brook, R. H., Kamberg, C., Hilborne, L. H., \& Leape, L. L. (1999). Underuse of cardiac procedures: Do women, ethnic minorities and the uninsured fail to receive Brogan et al. (2006) needed revascularization? Annals of Internal Medicine, 130, 183-192. 
Brogan, G. X., Calvin, J. E., Chen, A. Y., Fintel, D. J., Delong, E. R., Gibler, W. B.,...Smith, S. C. (2006). Insurance coverage and care of patients with no-st-segment elevation acute coronary syndrome.Annals of Internal Medicine, 145, 739-748.

Bugiardini, R., Goodman, S. G., Fitchett, D., Langer, A., Manfrini, O., Yan, A. T., \& Yan, R. T. (2011).Factors influencing underutilization of evidence-based therapies in women.European Heart Journal, 32, 1337-1344.

Buring, J. E., Cook, N. R., Gaziano, J. M., Manson, J. E., Rexrode, K. M., Sesso, H. D., \& Weinstein, A. R. (2008). The joint effects of physical activity and body mass index on coronary heart disease risk in women. Archives of Internal Medicine, 168(8), 884-890.

Centers For Disease Control and Prevention (2007). Leading causes of death. Retrieved from http://www.cdc.gov/nchs/fastats/heart.htm

Centers for Disease Control and Prevention. (2010). Prevalence of heart disease---United States, 2005. MMWR, 56.113-118.

Centers for Medicare and Medicaid Services 2012. Retrieved from www.cms.gov/

Chaitman, B. R., Kargl, D., Miller, D. D., Romeis, J. C., Shaw, L. J., \&Younis, L. T. (1994). Gender difference in the noninvasive evaluation and management of patients with suspected coronary artery disease. Annals of Internal Medicine, 120, 359-366.

Clark, A. M., Hartling, L., McAlister, F. A., \& Vandermeer, B. (2005). Meta-analysis: Secondary prevention programs for patients with coronary artery disease. Annals of Internal Medicine, 143, 659-672.

Curtis, M. J., Dzavik, V., Faris, P. D., Galbraith, P. D., Ghali, W. A., Knudtson, M. L.,...Sanders, L. D. (2002). Sex difference in access to coronary revascularization after cardiac 
catheterization: Importance of detailed clinical data. Annals of Internal Medicine, 136, 723-732.

Dearing, J. W. (2009). Applying diffusion of innovation theory to intervention development. Research on Social Work Practice, 19:503-518.

Gao, X., Guadagnoli, E., Gurwitz, J. H., Hauptman, P. J., McLaughlin, T. J., Soumerai, S. B., \& Wilson, D. J. (1997). Delayed hospital presentation in patients who have had acute myocardial infarction. Annals of Internal Medicine, 126, 593-599.

Goldberg, R. J., Gore, J. M., Krumholz, H. M., Vaccarino, V., \&Yarzebski, J. (2001). Sex differences in 2-year mortality after hospital discharge for myocardial infarction. Annals of Internal Medicine, 134, 173-181.

Krumholz, H. M., Ordin, D. L., Radford, M. J., Rathore, S. S., \& Wang, Y. (2002). Sex differences in cardiac catheterization after acute myocardial infarction: the role of procedure appropriateness. Annals of Internal Medicine, 137, 487-493.

Mercer County Behavioral Prevalence Report (2004-2008). Retrieved from http://www.wvdhhr.org/bph/hsc/pubs/profiles/2008/cp28b1.htm

Rogers, E. M. (2003). Diffusion of Innovations (3rd ed.). New York, NY: Simon and Schuster. Salob, M.(n.d.). Rural Appalachia: disparities within disparities. Retrieved from http://www.mountainpeeksmag.com/salobstudy.htm

Shirato and Swan (2010). Women and cardiovascular disease: an evidentiary review. MEDSURG Nursing, 19.282-306.

Scottish Intercollegiate Guidelines Network (2008). Retrieved from http://www.sign.ac.uk/methodology/checklists.html 
US Census Bureau, State and County Quickfacts (2012). Retrieved from http://quickfacts.census.gov/qfd/state/54/54055.html

WV Bureau for Public Health, Health Statistics Center 2012). West Virginia Bureau for Public Health, Health Statistics Center.Retrieved from http://www.wvdhhr.org/bph/hsc/pubs/brfss/2009_2010/BRFS2009_2010.pdf 


\section{Table I}

High risk behavior for CAD (West Virginia Behavioral Risk Factor Survey Report 2004-2008).

\begin{tabular}{|l|c|c|}
\hline Risk Factor & WV & US \\
\hline Obesity & $31.90 \%$ & $26.70 \%$ \\
\hline Diabetes & $11.90 \%$ & $8.80 \%$ \\
\hline Hypertension & $33.60 \%$ & $25.80 \%$ \\
\hline Hypercholesterolemia & $42 \%$ & $(? ?)$ \\
\hline Tobacco smoker & $26.50 \%$ & $18.40 \%$ \\
\hline Sedentary & $20.90 \%$ & $18.50 \%$ \\
\hline Heart Attack & $14.20 \%$ & $4.30 \%$ \\
\hline Angina & $8.10 \%$ & $4.40 \%$ \\
\hline
\end{tabular}




\section{Table II}

Mercer County Behavioral Prevalence Report (2004-2008)

\begin{tabular}{|c|c|c|}
\hline Risk Factor & Mercer County & WV \\
\hline Obesity & $25.60 \%$ & $30.30 \%$ \\
\hline Diabetes & $12.50 \%$ & $11.20 \%$ \\
\hline Hypertension & $35.50 \%$ & $32.80 \%$ \\
\hline Tobacco smoker & $29.60 \%$ & $26.50 \%$ \\
\hline Sedentary & $24.30 \%$ & $20.90 \%$ \\
\hline Heart Attack/Angina/Stroke & $15.80 \%$ & $13.50 \%$ \\
\hline
\end{tabular}




\section{Table III}

Acute Coronary Syndrome in Women Intervention Participants Characteristics and demographics.

\begin{tabular}{|c|c|}
\hline Characteristic & Number (\%) \\
\hline \multicolumn{2}{|l|}{ Gender } \\
\hline Female & $45(83.3 \%)$ \\
\hline Male & $9(1.7 \%)$ \\
\hline \multicolumn{2}{|l|}{ Age } \\
\hline $18-30$ & $9 \quad(16.7 \%)$ \\
\hline $31-40$ & $15(27.8 \%)$ \\
\hline $41-50$ & $19(35.2 \%)$ \\
\hline $51-60$ & $7 \quad(13 \%)$ \\
\hline$>-60$ & $4 \quad(7.3 \%)$ \\
\hline \multicolumn{2}{|l|}{ Licensure } \\
\hline RN & $41(75.9 \%)$ \\
\hline PA & $4 \quad(7.4 \%)$ \\
\hline NP & $3 \quad(5.6 \%)$ \\
\hline Physician & $6 \quad(11.1 \%)$ \\
\hline
\end{tabular}




\section{Table IV}

Provider Knowledge, Pre and Post Test

\begin{tabular}{|c|c|c|}
\hline Question Number & $\begin{array}{l}\text { Pre-Test: Number of } \\
\text { Participants that Answered } \\
\text { Correctly } \\
\text { Number }(\%)\end{array}$ & $\begin{array}{l}\text { Post-Test: Number of } \\
\text { Participants that Answered } \\
\text { Correctly } \\
\text { Number }(\%)\end{array}$ \\
\hline $\begin{array}{l}\text { 1- Who is responsible for } \\
\text { delays in the treatment of } \\
\text { women with ACS? }\end{array}$ & $45(83.3)$ & $39(72.2)$ \\
\hline $\begin{array}{l}\text { 2- What are the atypical signs } \\
\text { and symptoms with which } \\
\text { women present to the ED? }\end{array}$ & $40(74.1)$ & $54(100)$ \\
\hline $\begin{array}{l}\text { 3- What are the CORE values } \\
\text { that are assessed with patients } \\
\text { with c/o chest pain in the ED? }\end{array}$ & $35(64.8)$ & $49(90.7)$ \\
\hline $\begin{array}{l}\text { 4- What will not help decrease } \\
\text { morbidity and mortality in } \\
\text { women who present with } \\
\text { ACS? }\end{array}$ & $42(77.8)$ & $50(92.6)$ \\
\hline $\begin{array}{l}\text { 5- What is the most typical } \\
\text { presentation of women with } \\
\text { ACS? }\end{array}$ & $19(35.2)$ & $51(94.4)$ \\
\hline $\begin{array}{l}\text { 6- Men with chest pain are } \\
\text { treated more rapidly in the ED } \\
\text { than women. }\end{array}$ & $49(90.7)$ & $53(98.1)$ \\
\hline $\begin{array}{l}\text { 7- Women are just as likely to } \\
\text { receive PCI or CABG as men. }\end{array}$ & $39(72.2)$ & $39(72.2)$ \\
\hline $\begin{array}{l}\text { 8- There is no difference in the } \\
\text { treatment of men and women } \\
\text { with ACS no matter what their } \\
\text { insurance is. }\end{array}$ & $24(44.4)$ & $41(75.9)$ \\
\hline $\begin{array}{l}\text { 9- What types of reasons do } \\
\text { women have for not seeking } \\
\text { treatment when they develop }\end{array}$ & $52(96.3)$ & $54(100)$ \\
\hline
\end{tabular}




\begin{tabular}{|c|c|c|}
\hline Question Number & $\begin{array}{l}\text { Pre-Test: Number of } \\
\text { Participants that Answered } \\
\text { Correctly } \\
\text { Number }(\%)\end{array}$ & $\begin{array}{l}\text { Post-Test: Number of } \\
\text { Participants that Answered } \\
\text { Correctly } \\
\text { Number }(\%)\end{array}$ \\
\hline \multicolumn{3}{|l|}{ chest pain? } \\
\hline $\begin{array}{l}\text { 10- How can a provider ensure } \\
\text { they are treating women with } \\
\text { ACS correctly? }\end{array}$ & $54(100)$ & $54(100)$ \\
\hline $\begin{array}{l}\text { 11- Who on the ED team can } \\
\text { help reduce delays in the } \\
\text { treatment and care of women } \\
\text { with ACS? }\end{array}$ & $48(88.9)$ & $53(98.1)$ \\
\hline $\begin{array}{l}\text { 12- What are typical signs and } \\
\text { symptoms of ACS that } \\
\text { patients present with? }\end{array}$ & $52(96.3)$ & $51(94.4)$ \\
\hline $\begin{array}{l}\text { 13- Choose all of the } \\
\text { following that are not CORE } \\
\text { measures as related to ACS } \\
\text { patients }\end{array}$ & $21(38.9)$ & $34(63.0)$ \\
\hline 14- What is not part of ACS? & $33(61.1)$ & $45(83.3)$ \\
\hline $\begin{array}{l}\text { 15- What are some nursing } \\
\text { and medical provider's } \\
\text { attitudes towards women with } \\
\text { chest pain? }\end{array}$ & $48(88.9)$ & $53(98.1)$ \\
\hline $\begin{array}{l}\text { 16- EMS personnel are more } \\
\text { aware that women present } \\
\text { with atypical sign and } \\
\text { symptoms of ACS than ED } \\
\text { personnel. }\end{array}$ & $28(51.9)$ & $36(66.7)$ \\
\hline $\begin{array}{l}\text { 17- Preventing delays in the } \\
\text { treatment of ACS decreases? }\end{array}$ & $46(85.2)$ & $51(94.1)$ \\
\hline $\begin{array}{l}\text { 18- What is the most effective } \\
\text { way to get the message out }\end{array}$ & $22(40.7)$ & $53(98.1)$ \\
\hline
\end{tabular}




\begin{tabular}{|l|l|l|}
\hline Question Number & $\begin{array}{l}\text { Pre-Test: Number of } \\
\text { Participants that Answered } \\
\text { Correctly } \\
\text { Number (\%) }\end{array}$ & $\begin{array}{l}\text { Post-Test: Number of } \\
\text { Participants that Answered } \\
\text { Correctly } \\
\text { Number (\%) }\end{array}$ \\
\hline about women with ACS? & 48 (88.9) \\
$\begin{array}{l}\text { 19- Higher perceived control } \\
\text { waser associated with? }\end{array}$ & $52(96.3)$ \\
\hline $\begin{array}{l}\text { 20- Women that are Dx with } \\
\text { ACS and undergo } \\
\text { percutaneous coronary } \\
\text { intervention are less likely to } \\
\text { receive. }\end{array}$ & $22(40.7)$ & $48(88.9)$ \\
\hline
\end{tabular}

Table V

Population and Population Age

\begin{tabular}{|l|l|l|}
\hline Age & $\begin{array}{l}\text { Male } \\
\text { Number (\%) }\end{array}$ & $\begin{array}{l}\text { Female } \\
\text { Number }(\%)\end{array}$ \\
\hline Total & $504 \quad(42.63)$ & $678 \quad(57.36)$ \\
\hline $18-49$ years & $230 \quad(42.8)$ & $307 \quad(57.1)$ \\
\hline $50-54$ years & $48 \quad(38.7)$ & $76 \quad(61.2)$ \\
\hline $55-64$ year & $98 \quad(43.9)$ & $125 \quad(56.0)$ \\
\hline $65-74$ years & $71 \quad(50)$ & $71 \quad(50)$ \\
\hline $75-84$ years & $42 \quad(39.6)$ & $64 \quad(60.3)$ \\
\hline Greater than -84 years & $15 \quad(30)$ & $35 \quad(70)$ \\
\hline
\end{tabular}


Table VI

EKG Less Than 10 Minutes.

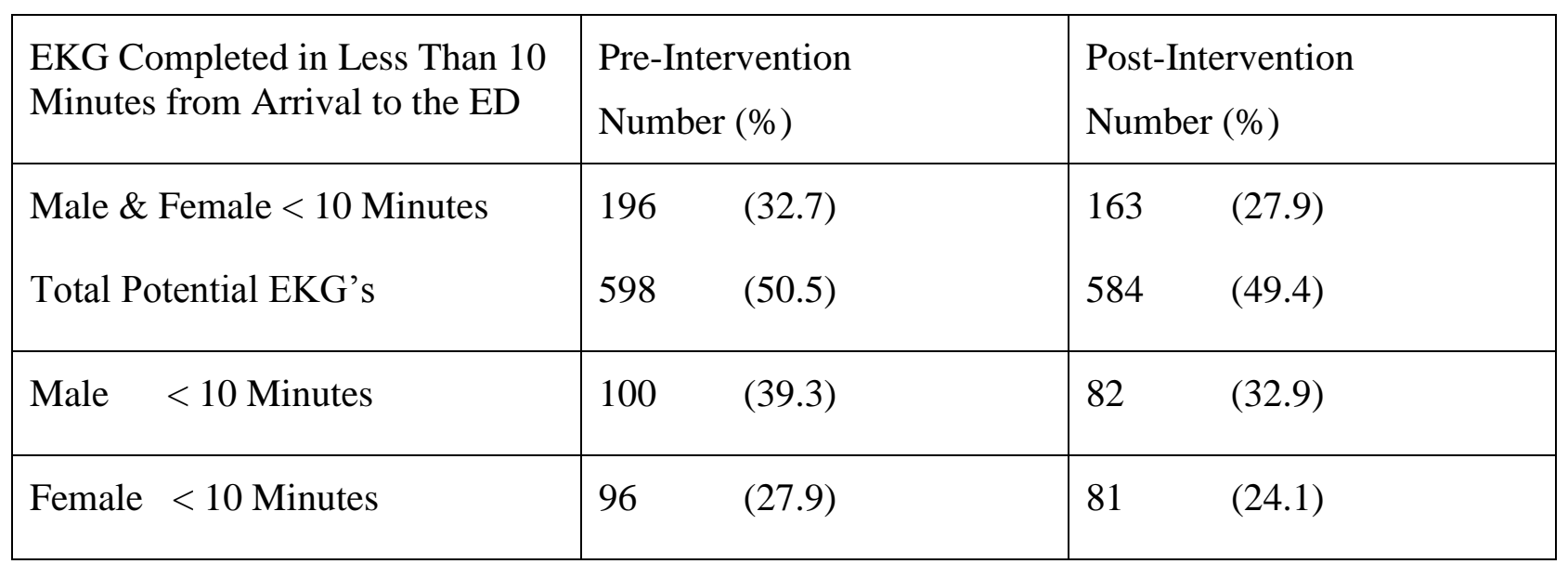




\section{Table VII}

TNKase Administration Less Than 30 Minutes.

\begin{tabular}{|c|c|c|}
\hline TNKase & $\begin{array}{l}\text { Pre-Intervention } \\
\text { Number }(\%)\end{array}$ & $\begin{array}{l}\text { Post-Intervention } \\
\text { Number }(\%)\end{array}$ \\
\hline Male \& Female $<30$ Minutes & $7 \quad(41.17)$ & $6 \quad(37.50)$ \\
\hline $\begin{array}{l}\text { Total Potential TNKase } \\
\text { Administration }\end{array}$ & $17 \quad(1.43)$ & $16 \quad(1.35)$ \\
\hline Male $<30$ Minutes & $(50)$ & (18) \\
\hline Female $<30$ Minutes & $2 \quad(28.57)$ & (80) \\
\hline
\end{tabular}




\section{Table VIII}

ASA Given in the ED.

\begin{tabular}{|l|ll|}
\hline ASA & $\begin{array}{l}\text { Actually Received ASA } \\
\text { Number (\%) }\end{array}$ \\
\hline Male / Female given in the ED & $871 \quad(73.6)$ \\
\hline $\begin{array}{l}\text { Total Female Evaluation Time } \\
\text { Frame }\end{array}$ & $496 \quad(41.9)$ \\
\hline $\begin{array}{l}\text { 1-Female Pre-Intervention } \\
\text { Given ASA in the ED } \\
\text { Potential 344 Females }\end{array}$ & $250 \quad(72.6)$ \\
$\begin{array}{l}\text { 2-Male Pre-Intervention Given } \\
\text { ASA in the ED } \\
\text { Potential 254 Males }\end{array}$ & 186 & $(73.2)$ \\
\hline $\begin{array}{l}\text { 1-Female Post Intervention } \\
\text { Given ASA in the ED } \\
\text { Potential 335 Females }\end{array}$ & 246 & $(73.4)$ \\
$\begin{array}{l}\text { 2-Male Post Intervention } \\
\text { Given ASA in the ED } \\
\text { Potential 249 Males }\end{array}$ & 189 & $(75.9)$ \\
\hline
\end{tabular}




\section{Appendix A}

Scientific Evidence Table

\begin{tabular}{|l|l|l|l|l|l|}
\hline Citation & $\begin{array}{l}\text { Aims, } \\
\text { Research } \\
\text { Questions or } \\
\text { Hypotheses }\end{array}$ & $\begin{array}{l}\text { Methodology: } \\
\text { Design, Site, } \\
\text { Sample }\end{array}$ & $\begin{array}{l}\text { Variables } \\
\text { and } \\
\text { Instrume } \\
\text { nts }\end{array}$ & Results & $\begin{array}{l}\text { Strengths and } \\
\text { Limitations }\end{array}$ \\
\hline $\begin{array}{l}\text { Adomaity } \\
\text { te et al. } \\
\text { (2008) }\end{array}$ & $\begin{array}{l}\text { The aim of the } \\
\text { research was } \\
\text { to evaluate } \\
\text { whether } \\
\text { routine } \\
\text { invasive } \\
\text { strategies } \\
\text { compared to } \\
\text { selective } \\
\text { invasive } \\
\text { strategies } \\
\text { improved } \\
\text { cardiac } \\
\text { outcomes }\end{array}$ & $\begin{array}{l}\text { Systematic } \\
\text { Review of ten } \\
\text { trials comprised of } \\
\text { 10,648 patients. } \\
\text { Mean age was } 62 \\
\text { years, most were } \\
\text { male, and the trials } \\
\text { were conducted in } \\
\text { Europe, North } \\
\text { America, South } \\
\text { Africa, \& South } \\
\text { Asia. }\end{array}$ & $\begin{array}{l}\text { The } \\
\text { researchers } \\
\text { concluded } \\
\text { that routine } \\
\text { invasive } \\
\text { strategies did } \\
\text { not reduce } \\
\text { poor } \\
\text { outcomes } \\
\text { including } \\
\text { death from } \\
\text { non-fatal MI. }\end{array}$ & $\begin{array}{l}\text { Mugstion, a } \\
\text { a clear focused } \\
\text { rigorous } \\
\text { literature } \\
\text { search, } \\
\text { methodology } \\
\text { was described. } \\
\text { Limitations of } \\
\text { the review } \\
\text { found that the } \\
\text { data was } \\
\text { heterogeneous } \\
\text { and insufficient } \\
\text { to determine } \\
\text { the aim of the } \\
\text { study; } \\
\text { methodology, } \\
\text { protocols, and } \\
\text { outcome } \\
\text { definitions } \\
\text { were different } \\
\text { among the } \\
\text { trials. }\end{array}$ \\
\hline
\end{tabular}




\begin{tabular}{|c|c|c|c|c|c|}
\hline Citation & $\begin{array}{l}\text { Aims, } \\
\text { Research } \\
\text { Questions or } \\
\text { Hypotheses }\end{array}$ & $\begin{array}{l}\text { Methodology: } \\
\text { Design, Site, } \\
\text { Sample }\end{array}$ & $\begin{array}{l}\text { Variables } \\
\text { and } \\
\text { Instrume } \\
\text { nts }\end{array}$ & Results & $\begin{array}{l}\text { Strengths and } \\
\text { Limitations }\end{array}$ \\
\hline $\begin{array}{l}\text { Afzal et } \\
\text { al. (2009) }\end{array}$ & $\begin{array}{l}\text { The aim of the } \\
\text { trial was to } \\
\text { determine } \\
\text { whether there } \\
\text { is a difference } \\
\text { in both } \\
\text { primary } \\
\text { (death, MI, or } \\
\text { stroke at six } \\
\text { months) and } \\
\text { secondary } \\
\text { outcomes } \\
\text { (death, MI, or } \\
\text { refractory } \\
\text { ischemia at six } \\
\text { months) in } \\
\text { early vs. } \\
\text { delayed } \\
\text { invasive } \\
\text { intervention. }\end{array}$ & $\begin{array}{l}\text { Completed a six } \\
\text { month randomized } \\
\text { control trial of } \\
3,031 \text { patients } \\
\text { experiencing ACS } \\
\text { who either } \\
\text { underwent early } \\
\text { ( } \leq 24 \text { hours after } \\
\text { randomization) or } \\
\text { delayed ( } \geq 36 \text { hours } \\
\text { after } \\
\text { randomization) } \\
\text { invasive } \\
\text { intervention. } 1593 \\
\text { in the early group } \\
\text { and } 1438 \text { in the } \\
\text { delayed group } \\
69.4 \% \text { were } \\
\text { female and median } \\
\text { age was } 65 \text { years. }\end{array}$ & $\begin{array}{l}\text { Dependent } \\
\text { variable } \\
\text { was } \\
\text { patients } \\
\text { with } \\
\text { primary } \\
\text { and } \\
\text { secondary } \\
\text { outcomes. } \\
\text { Independe } \\
\text { nt } \\
\text { variables } \\
\text { were early } \\
\text { interventio } \\
\text { n and } \\
\text { delayed } \\
\text { interventio } \\
\text { n. }\end{array}$ & $\begin{array}{l}\text { The trial } \\
\text { concluded } \\
\text { there was not } \\
\text { a significant } \\
\text { difference in } \\
\text { preventing } \\
\text { primary } \\
\text { outcomes } \\
\text { except in the } \\
\text { high risk } \\
\text { patients; there } \\
\text { is significant } \\
\text { difference in } \\
\text { preventing } \\
\text { secondary } \\
\text { outcomes at } \\
\text { six months } \\
\text { with early } \\
\text { invasive } \\
\text { intervention. }\end{array}$ & $\begin{array}{l}\text { Strengths of } \\
\text { the study were } \\
\text { there were a } \\
\text { clearly focused } \\
\text { question, } \\
\text { randomization, } \\
\text { concealment, } \\
\text { blinding, and } \\
\text { reliable, } \\
\text { measured } \\
\text { outcomes. The } \\
\text { weakness of } \\
\text { the study was } \\
\text { that even with } \\
\text { a large sample } \\
\text { size } n>3000 \text {; } \\
\text { the trial might } \\
\text { have still been } \\
\text { underpowered. }\end{array}$ \\
\hline
\end{tabular}




\begin{tabular}{|c|c|c|c|c|c|}
\hline Citation & $\begin{array}{l}\text { Aims, } \\
\text { Research } \\
\text { Questions or } \\
\text { Hypotheses }\end{array}$ & $\begin{array}{l}\text { Methodology: } \\
\text { Design, Site, } \\
\text { Sample }\end{array}$ & $\begin{array}{l}\text { Variables } \\
\text { and } \\
\text { Instrume } \\
\text { nts }\end{array}$ & Results & $\begin{array}{l}\text { Strengths and } \\
\text { Limitations }\end{array}$ \\
\hline $\begin{array}{l}\text { Aitken et } \\
\text { al. (2009) }\end{array}$ & $\begin{array}{l}\text { The aim of the } \\
\text { trial was to } \\
\text { reduce pre- } \\
\text { hospital delays } \\
\text { in seeking } \\
\text { emergent care } \\
\text { when } \\
\text { symptoms of } \\
\text { ACS develop. }\end{array}$ & $\begin{array}{l}\text { Completed a } \\
\text { twelve month } \\
\text { randomized } \\
\text { controlled trial to } \\
\text { determine the } \\
\text { effects of an } \\
\text { education and } \\
\text { counseling } \\
\text { intervention } \\
\text { among 3,522 } \\
\text { participants with } \\
\text { CAD on } \\
\text { knowledge, } \\
\text { attitudes, and } \\
\text { beliefs about ACS } \\
\text { including the } \\
\text { appropriate } \\
\text { response to } \\
\text { symptoms. The } \\
\text { study was } \\
\text { conducted at five } \\
\text { universities in the } \\
\text { US and one in } \\
\text { Australia. }\end{array}$ & $\begin{array}{l}\text { Dependent } \\
\text { variables } \\
\text { were } \\
\text { knowledge } \\
\text {, attitudes, } \\
\text { beliefs, } \\
\text { and } \\
\text { response } \\
\text { to ACS } \\
\text { symptoms. } \\
\text { Independe } \\
\text { nt variable } \\
\text { was an } \\
\text { education } \\
\text { and } \\
\text { counseling } \\
\text { interventio } \\
\text { n. }\end{array}$ & $\begin{array}{l}\text { The trial } \\
\text { concluded } \\
\text { that the } \\
\text { intervention } \\
\text { did increase } \\
\text { participant } \\
\text { knowledge, } \\
\text { attitudes, and } \\
\text { beliefs about } \\
\text { ACS and their } \\
\text { response to } \\
\text { ACS } \\
\text { symptom. } \\
\text { Additionally, } \\
\text { participants } \\
\text { with more } \\
\text { control over } \\
\text { their disease } \\
\text { in the study } \\
\text { found that } \\
\text { they had more } \\
\text { positive } \\
\text { attitudes } \\
\text { compared } \\
\text { with } \\
\text { participants } \\
\text { with high } \\
\text { anxiety was } \\
\text { associated } \\
\text { with less } \\
\text { knowledge, } \\
\text { poor attitudes, } \\
\text { and beliefs of } \\
\text { ACS }\end{array}$ & $\begin{array}{l}\text { Strengths of } \\
\text { the study were } \\
\text { clearly focused } \\
\text { question, } \\
\text { description of } \\
\text { methodology } \\
\text { was well } \\
\text { covered, and } \\
\text { study quality is } \\
\text { assessed. } \\
\text { Weaknesses } \\
\text { were that } \\
\text { methodology, } \\
\text { protocols, and } \\
\text { outcome } \\
\text { definitions } \\
\text { differed among } \\
\text { the providers. }\end{array}$ \\
\hline
\end{tabular}




\begin{tabular}{|c|c|c|c|c|c|}
\hline Citation & $\begin{array}{l}\text { Aims, } \\
\text { Research } \\
\text { Questions or } \\
\text { Hypotheses }\end{array}$ & $\begin{array}{l}\text { Methodology: } \\
\text { Design, Site, } \\
\text { Sample }\end{array}$ & $\begin{array}{l}\text { Variables } \\
\text { and } \\
\text { Instrume } \\
\text { nts }\end{array}$ & Results & $\begin{array}{l}\text { Strengths and } \\
\text { Limitations }\end{array}$ \\
\hline $\begin{array}{l}\text { Akhter et } \\
\text { al. (2009) }\end{array}$ & $\begin{array}{l}\text { The aim of the } \\
\text { study was to } \\
\text { determine if } \\
\text { there was a } \\
\text { statistical } \\
\text { difference } \\
\text { between men } \\
\text { and women in } \\
\text { post- } \\
\text { intervention } \\
\text { outcomes. Of } \\
\text { the } \\
\text { population, } \\
55,691 \\
\text { presented with } \\
\text { unstable } \\
\text { angina or non- } \\
\text { STEMI, } \\
\text { 12,335 } \\
\text { presented with } \\
\text { STEMI. }\end{array}$ & $\begin{array}{l}\text { Completed a } \\
\text { descriptive } \\
\text { retrospective } \\
\text { cohort study of } \\
199,690 \text { patients } \\
\text { (131,664 men and } \\
68,026 \text { women) } \\
\text { who were } \\
\text { presented to the } \\
\text { hospital with } \\
\text { ACS. Data was } \\
\text { reported to the } \\
\text { ACC-NCDR from } \\
470 \text { sites that } \\
\text { conducted PCI. }\end{array}$ & & $\begin{array}{l}\text { The study } \\
\text { concluded } \\
\text { that even } \\
\text { though } \\
\text { women were } \\
\text { less likely to } \\
\text { receive } \\
\text { certain } \\
\text { medications } \\
\text { than men, the } \\
\text { rate of } \\
\text { complications } \\
\text { following } \\
\text { revascularizat } \\
\text { ion were } \\
\text { higher in } \\
\text { women, more } \\
\text { specifically } \\
\text { bleeding. } \\
\text { However, } \\
\text { women were } \\
\text { actually less } \\
\text { likely than } \\
\text { men to have } \\
\text { stent } \\
\text { thrombosis } \\
\text { (0.43\% vs. } \\
0.57 \% \text {, } \\
\text { p=0.0003). } \\
\text { The rate of } \\
\text { mortality was } \\
\text { not } \\
\text { significantly } \\
\text { different. } \\
\text { (OR 0.97, } \\
95 \% \text { CI, } 0.88 \\
\text { to } 1.07, \\
\text { p=0.52). }\end{array}$ & $\begin{array}{l}\text { The strengths } \\
\text { of the study } \\
\text { were a clearly } \\
\text { appropriate } \\
\text { question, the } \\
\text { groups were } \\
\text { comparative; } \\
\text { the outcomes } \\
\text { are clearly } \\
\text { defined, and } \\
\text { CIs are } \\
\text { provided. } \\
\text { Limitations } \\
\text { were not } \\
\text { discussed. }\end{array}$ \\
\hline
\end{tabular}




\begin{tabular}{|c|c|c|c|c|c|}
\hline Citation & $\begin{array}{l}\text { Aims, } \\
\text { Research } \\
\text { Questions or } \\
\text { Hypotheses }\end{array}$ & $\begin{array}{l}\text { Methodology: } \\
\text { Design, Site, } \\
\text { Sample }\end{array}$ & $\begin{array}{l}\text { Variables } \\
\text { and } \\
\text { Instrume } \\
\text { nts }\end{array}$ & Results & $\begin{array}{l}\text { Strengths and } \\
\text { Limitations }\end{array}$ \\
\hline $\begin{array}{l}\text { Arslanian } \\
\text {-Engoren } \\
(2004)\end{array}$ & $\begin{array}{l}\text { The aim of the } \\
\text { study was to } \\
\text { determine if } \\
\text { triage nurse } \\
\text { initial } \\
\text { decisions } \\
\text { influenced the } \\
\text { admission or } \\
\text { discharge } \\
\text { diagnosis of } \\
\text { patients with } \\
\text { ACS. }\end{array}$ & $\begin{array}{l}\text { Completed a } \\
\text { prospective } \\
\text { descriptive cohort } \\
\text { study of } 13 \text { triage } \\
\text { nurses and } 108 \\
\text { patients. } 65 \% \\
\text { female Mean age } \\
\text { of } 44 \text { years Mean } \\
\text { years as a RN } 16 . \\
\text { Mean years in the } \\
\text { ED } 12,15 \% \text { had } \\
\text { Diplomas, } 38 \% \\
\text { had AS Degrees, } \\
\text { and } 46 \% \text { had } \\
\text { BSN. } 69 \% \text { were } \\
\text { full time, and } 23 \% \\
\text { had CEN } \\
\text { certifications. The } \\
\text { study location was } \\
\text { in a ED in the } \\
\text { Mid-West. }\end{array}$ & & $\begin{array}{l}\text { The study } \\
\text { concluded } \\
\text { that the triage } \\
\text { nurse did not } \\
\text { have a } \\
\text { significant } \\
\text { ability to } \\
\text { predict ACS } \\
\text { in patients. }\end{array}$ & $\begin{array}{l}\text { Strengths of } \\
\text { the study } \\
\text { included, an } \\
\text { appropriate } \\
\text { clearly focused } \\
\text { question, } \\
\text { comparable } \\
\text { groups, } \\
\text { outcomes are } \\
\text { clearly defined. } \\
\text { Limitations of } \\
\text { the study were } \\
\text { that there was a } \\
\text { reliance on a } \\
\text { convenience } \\
\text { sample of ED } \\
\text { nurses that } \\
\text { worked in the } \\
\text { mid-west and } \\
\text { small number } \\
\text { of participants. }\end{array}$ \\
\hline
\end{tabular}




\begin{tabular}{|c|c|c|c|c|c|}
\hline Citation & $\begin{array}{l}\text { Aims, } \\
\text { Research } \\
\text { Questions or } \\
\text { Hypotheses }\end{array}$ & $\begin{array}{l}\text { Methodology: } \\
\text { Design, Site, } \\
\text { Sample }\end{array}$ & $\begin{array}{l}\text { Variables } \\
\text { and } \\
\text { Instrume } \\
\text { nts }\end{array}$ & Results & $\begin{array}{l}\text { Strengths and } \\
\text { Limitations }\end{array}$ \\
\hline $\begin{array}{l}\text { Baker et } \\
\text { al. (2009) }\end{array}$ & $\begin{array}{l}\text { The aim of the } \\
\text { study was to } \\
\text { determine if } \\
\text { an } \\
\text { intervention } \\
\text { conducted } \\
\text { specifically } \\
\text { for patients } \\
\text { with CAD } \\
\text { would reduce } \\
\text { pre-hospital } \\
\text { delay times. } \\
\text { The } \\
\text { intervention } \\
\text { looked at } \\
\text { women, } \\
\text { nurses and } \\
\text { physicians } \\
\text { knowledge, } \\
\text { attitude, and } \\
\text { beliefs about } \\
\text { ACS in } \\
\text { women. }\end{array}$ & $\begin{array}{l}\text { Conducted a } \\
\text { randomized } \\
\text { clinical trial of } \\
3,522 \text { participants } \\
\text { with diagnosed } \\
\text { CAD There were } \\
2393 \text { male and } \\
1129 \text { female } \\
\text { participants. } 1,777 \\
\text { were in the } \\
\text { experimental } \\
\text { group and 1,745 in } \\
\text { the control group. } \\
\text { The participants } \\
\text { were from the US } \\
\text { (56\%), Australia } \\
\text { or New Zealand } \\
\text { (44\%). At } 24 \\
\text { months there were } \\
13.7 \% \text { lost in the } \\
\text { control group and } \\
11 \% \text { lost in the } \\
\text { intervention } \\
\text { group. }\end{array}$ & $\begin{array}{l}\text { Dependent } \\
\text { Variables } \\
\text { were pre- } \\
\text { hospital } \\
\text { delay } \\
\text { times. The } \\
\text { independe } \\
\text { nt } \\
\text { variables } \\
\text { were } \\
\text { Knowledg } \\
\text { e, } \\
\text { attitudes, } \\
\text { and beliefs } \\
\text { about } \\
\text { ACS. }\end{array}$ & $\begin{array}{l}\text { The trial } \\
\text { concluded } \\
\text { that there was } \\
\text { no significant } \\
\text { difference of } \\
\text { the delays in } \\
\text { presenting to } \\
\text { the hospital in } \\
\text { patients with } \\
\text { ACS who } \\
\text { develop chest } \\
\text { pain. }\end{array}$ & $\begin{array}{l}\text { Strengths of } \\
\text { the study } \\
\text { included that } \\
\text { the study was a } \\
\text { blind } \\
\text { randomized } \\
\text { study, } \\
\text { conducted over } \\
\text { a two year } \\
\text { period, written } \\
\text { informed } \\
\text { consent was } \\
\text { provided, } \\
\text { similar } \\
\text { treatment and } \\
\text { control groups, } \\
\text { and study } \\
\text { methods were } \\
\text { well described. } \\
\text { Weaknesses } \\
\text { were, no } \\
\text { clearly focused } \\
\text { question, the } \\
\text { one-on-one } \\
\text { intervention } \\
\text { was probably } \\
\text { too short } \\
\text { considering the } \\
\text { age of the } \\
\text { participants. }\end{array}$ \\
\hline
\end{tabular}




\begin{tabular}{|c|c|c|c|c|c|}
\hline Citation & $\begin{array}{l}\text { Aims, } \\
\text { Research } \\
\text { Questions or } \\
\text { Hypotheses }\end{array}$ & $\begin{array}{l}\text { Methodology: } \\
\text { Design, Site, } \\
\text { Sample }\end{array}$ & $\begin{array}{l}\text { Variables } \\
\text { and } \\
\text { Instrume } \\
\text { nts }\end{array}$ & Results & $\begin{array}{l}\text { Strengths and } \\
\text { Limitations }\end{array}$ \\
\hline $\begin{array}{l}\text { Barrett- } \\
\text { Connor et } \\
\text { al. (2003) }\end{array}$ & $\begin{array}{l}\text { The aim of the } \\
\text { study was to } \\
\text { determine the } \\
\text { use of } \\
\text { secondary } \\
\text { prevention } \\
\text { treatment in } \\
\text { women, } \\
\text { assessing risk } \\
\text { factors and } \\
\text { event rates. }\end{array}$ & $\begin{array}{l}\text { Completed a } \\
\text { prospective cohort } \\
\text { of clinical trial of } \\
2,763 \\
\text { postmenopausal } \\
\text { participants with } \\
\text { known CAD from } \\
\text { the Heart and } \\
\text { Estrogen/progester } \\
\text { one Replacement } \\
\text { Study The mean } \\
\text { age was } 66 \text { years } \\
\text { for both groups }\end{array}$ & & $\begin{array}{l}\text { The study } \\
\text { concluded } \\
\text { that despite } \\
\text { women with } \\
\text { high risk for } \\
\text { MI, or death } \\
\text { from CAD, } \\
\text { the use of } \\
\text { secondary } \\
\text { prevention } \\
\text { medications, } \\
\text { even in the } \\
\text { most high risk } \\
\text { patients were } \\
\text { underutilized. }\end{array}$ & $\begin{array}{l}\text { Strengths of } \\
\text { the study were; } \\
\text { a clearly } \\
\text { focused } \\
\text { question, } \\
\text { comparative } \\
\text { groups, } \\
\text { outcomes } \\
\text { clearly defined, } \\
\text { CIs were used, } \\
\text { and blinding } \\
\text { was used. } \\
\text { Weaknesses } \\
\text { were that } \\
\text { voluntary } \\
\text { participants } \\
\text { were used in a } \\
\text { secondary } \\
\text { prevention } \\
\text { trial; the } \\
\text { sample } \\
\text { population may } \\
\text { differ from the } \\
\text { general } \\
\text { population of } \\
\text { women with } \\
\text { CAD. }\end{array}$ \\
\hline
\end{tabular}




\begin{tabular}{|c|c|c|c|c|c|}
\hline Citation & $\begin{array}{l}\text { Aims, } \\
\text { Research } \\
\text { Questions or } \\
\text { Hypotheses }\end{array}$ & $\begin{array}{l}\text { Methodology: } \\
\text { Design, Site, } \\
\text { Sample }\end{array}$ & $\begin{array}{l}\text { Variables } \\
\text { and } \\
\text { Instrume } \\
\text { nts }\end{array}$ & Results & $\begin{array}{l}\text { Strengths and } \\
\text { Limitations }\end{array}$ \\
\hline $\begin{array}{l}\text { Bell et al. } \\
\text { (1999) }\end{array}$ & $\begin{array}{l}\text { The aim of the } \\
\text { review was to } \\
\text { determine if } \\
\text { there was a } \\
\text { difference in } \\
\text { who receives } \\
\text { needed } \\
\text { revascularizati } \\
\text { on among } \\
\text { women, ethnic } \\
\text { minorities, } \\
\text { and the } \\
\text { uninsured } \\
\text { when there } \\
\text { was on-site } \\
\text { availability of } \\
\text { revascularizati } \\
\text { on. }\end{array}$ & $\begin{array}{l}\text { Conducted a } \\
\text { retrospective, } \\
\text { randomized } \\
\text { medical record } \\
\text { review on } 631 \\
\text { patients from } \\
\text { thirteen of twenty } \\
\text { four hospitals in } \\
\text { New York City } \\
\text { who had coronary } \\
\text { angiography. } 41 \% \\
\text { female, ages } 18 \\
\text { years to } 79 \text { years. } \\
\text { Onsite participants } \\
\text { N=464 to off-site } \\
\text { participants } \\
n=167 \text {. }\end{array}$ & & $\begin{array}{l}\text { The review } \\
\text { concluded } \\
\text { that patients } \\
\text { in New York } \\
\text { City receive } \\
\text { cardiac } \\
\text { revascularizat } \\
\text { ion when } \\
\text { needed } \\
\text { without } \\
\text { regard to sex, } \\
\text { ethnicity or } \\
\text { ability to pay. } \\
\text { However, } \\
\text { there were } \\
\text { patients who } \\
\text { needed a } \\
\text { procedure and } \\
\text { did not get } \\
\text { one. More } \\
\text { often, if one } \\
\text { was treated at } \\
\text { a hospital that } \\
\text { did not have } \\
\text { the capability } \\
\text { of performing } \\
\text { the procedure } \\
\text { onsite and } \\
\text { they did not } \\
\text { have } \\
\text { insurance, } \\
\text { they were } \\
\text { more likely } \\
\text { not to receive } \\
\text { the needed } \\
\text { procedure. }\end{array}$ & $\begin{array}{l}\text { The strengths } \\
\text { of the study } \\
\text { were a clearly } \\
\text { focused } \\
\text { question was } \\
\text { used, the } \\
\text { groups were } \\
\text { comparable, } \\
\text { the outcomes } \\
\text { were clearly } \\
\text { defined, and } \\
\text { CIs were used. } \\
\text { Weaknesses } \\
\text { were self- } \\
\text { reported } \\
\text { ethnicity may } \\
\text { produce bias, } \\
\text { off-site hospital } \\
\text { sample size } \\
\text { was low, the } \\
\text { study may not } \\
\text { have identified } \\
\text { patients that } \\
\text { refused } \\
\text { recommended } \\
\text { procedures. }\end{array}$ \\
\hline
\end{tabular}




\begin{tabular}{|c|c|c|c|c|c|}
\hline Citation & $\begin{array}{l}\text { Aims, } \\
\text { Research } \\
\text { Questions or } \\
\text { Hypotheses }\end{array}$ & $\begin{array}{l}\text { Methodology: } \\
\text { Design, Site, } \\
\text { Sample }\end{array}$ & $\begin{array}{l}\text { Variables } \\
\text { and } \\
\text { Instrume } \\
\text { nts }\end{array}$ & Results & $\begin{array}{l}\text { Strengths and } \\
\text { Limitations }\end{array}$ \\
\hline $\begin{array}{l}\text { Brogan et } \\
\text { al. (2006) }\end{array}$ & $\begin{array}{l}\text { The aim of the } \\
\text { study was to } \\
\text { compare the } \\
\text { treatment of } \\
\text { non-STEMI } \\
\text { ACS patterns } \\
\text { between } \\
\text { different } \\
\text { insurances. }\end{array}$ & $\begin{array}{l}\text { Completed a } \\
\text { retrospective } \\
\text { observational } \\
\text { analysis that } \\
\text { compared a total } \\
\text { of } 86,895 \text { ( } 37,345 \\
\text { Medicaid and } \\
59,550 \text { Medicare) } \\
\text { from (358 and } \\
359) \text { hospitals } \\
\text { respectively to the } \\
\text { treatment with } \\
\text { patients that have } \\
\text { similar age with } \\
\text { either HMO or } \\
\text { private insurance } \\
\text { coverage. there } \\
\text { were } 39 \% \text { female } \\
\text { age <65 with } \\
\text { Medicaid } 27.5 \% \\
\text { with HMO or Pvt } \\
\text { Ins. There } \\
\text { were } 48 \% \text { females } \\
\geq 65 \text { with } \\
\text { Medicare and } \\
43.2 \% \text { with HMO } \\
\text { or Pvt Ins. }\end{array}$ & & $\begin{array}{l}\text { The study } \\
\text { concluded } \\
\text { that Medicaid } \\
\text { patients were } \\
\text { less likely to } \\
\text { have } \\
\text { evidenced- } \\
\text { based } \\
\text { treatment for } \\
\text { ACS with } \\
\text { higher rate of } \\
\text { mortality than } \\
\text { patients with } \\
\text { Medicare, } \\
\text { private } \\
\text { insurance, and } \\
\text { HMO. }\end{array}$ & $\begin{array}{l}\text { Strengths of the } \\
\text { study were } \\
\text { used. a clearly } \\
\text { focused } \\
\text { question, CI's } \\
\text { were used, } \\
\text { comparisons } \\
\text { were made } \\
\text { between } \\
\text { participants, } \\
\text { comparative } \\
\text { populations } \\
\text { were used, and } \\
\text { cofounders were } \\
\text { identified. A } \\
\text { limitation of the } \\
\text { study was that } \\
\text { the study was } \\
\text { unable to } \\
\text { determine if } \\
\text { Medicaid and } \\
\text { Medicare } \\
\text { patients did not } \\
\text { receive invasive } \\
\text { interventions at } \\
\text { the same rate as } \\
\text { HMO and } \\
\text { private } \\
\text { insurance } \\
\text { because the } \\
\text { procedures were } \\
\text { underutilized in } \\
\text { Medicaid/Medic } \\
\text { are insurance or } \\
\text { if the } \\
\text { procedures were } \\
\text { over utilized in } \\
\text { HMO and } \\
\text { private } \\
\text { insurance for } \\
\text { monetary gain. }\end{array}$ \\
\hline
\end{tabular}




\begin{tabular}{|c|c|c|c|c|c|}
\hline Citation & $\begin{array}{l}\text { Aims, } \\
\text { Research } \\
\text { Questions or } \\
\text { Hypotheses }\end{array}$ & $\begin{array}{l}\text { Methodology: } \\
\text { Design, Site, } \\
\text { Sample }\end{array}$ & $\begin{array}{l}\text { Variables } \\
\text { and } \\
\text { Instrume } \\
\text { nts }\end{array}$ & Results & $\begin{array}{l}\text { Strengths and } \\
\text { Limitations }\end{array}$ \\
\hline $\begin{array}{l}\text { Bugiardin } \\
\text { i et al. } \\
(2011)\end{array}$ & $\begin{array}{l}\text { The aim of the } \\
\text { review was to } \\
\text { determine if } \\
\text { there were } \\
\text { differences } \\
\text { among men } \\
\text { and women in } \\
\text { the use of } \\
\text { cardiovascular } \\
\text { medication for } \\
\text { ACS. }\end{array}$ & $\begin{array}{l}\text { Completed a } \\
\text { retrospective } \\
\text { cohort study of the } \\
\text { Canadian Registry } \\
\text { of ACS I and II } \\
\text { that included } 6558 \\
\text { patients that had a } \\
\text { final diagnosis of } \\
\text { ACS. There were } \\
4,471 \text { women and } \\
2,087 \text { men. The } \\
\text { mean age of } \\
\text { participants was } \\
67 \text { years. The } \\
\text { participants were } \\
\text { from the Canadian } \\
\text { ACS registry. }\end{array}$ & & $\begin{array}{l}\text { The } \\
\text { conclusion of } \\
\text { the review } \\
\text { suggested that } \\
\text { despite a } \\
\text { women's age, } \\
\text { Killip class } \\
\text { and } \\
\text { physician's } \\
\text { assessment } \\
\text { given } \\
\text { rationale that } \\
\text { could prohibit } \\
\text { the use of } \\
\text { some } \\
\text { medication } \\
\text { such as beta- } \\
\text { blockers, } \\
\text { there still was } \\
\text { no significant } \\
\text { reason to } \\
\text { withhold } \\
\text { evidence- } \\
\text { based } \\
\text { therapies in } \\
\text { women such } \\
\text { as lipid } \\
\text { modifying } \\
\text { agents and } \\
\text { ACE } \\
\text { inhibitors. }\end{array}$ & $\begin{array}{l}\text { Strengths of } \\
\text { the study were } \\
\text { appropriate } \\
\text { clearly focused } \\
\text { question was } \\
\text { used; } \\
\text { comparable } \\
\text { groups, } \\
\text { outcomes } \\
\text { clearly defined, } \\
\text { and CIs were } \\
\text { used. } \\
\text { Weaknesses } \\
\text { were adherence } \\
\text { to EBP was not } \\
\text { used } \\
\text { throughout the } \\
\text { study period, } \\
\text { relative } \\
\text { contraindicatio } \\
\text { ns to } \\
\text { medications } \\
\text { were not } \\
\text { evaluated. }\end{array}$ \\
\hline
\end{tabular}




\begin{tabular}{|c|c|c|c|c|c|}
\hline Citation & $\begin{array}{l}\text { Aims, } \\
\text { Research } \\
\text { Questions or } \\
\text { Hypotheses }\end{array}$ & $\begin{array}{l}\text { Methodology: } \\
\text { Design, Site, } \\
\text { Sample }\end{array}$ & $\begin{array}{l}\text { Variables } \\
\text { and } \\
\text { Instrume } \\
\text { nts }\end{array}$ & Results & $\begin{array}{l}\text { Strengths and } \\
\text { Limitations }\end{array}$ \\
\hline $\begin{array}{l}\text { Buring et } \\
\text { al. (2008) }\end{array}$ & $\begin{array}{l}\text { The aim of the } \\
\text { study was to } \\
\text { determine if } \\
\text { the combined } \\
\text { association of } \\
\text { physical } \\
\text { activity and } \\
\text { body mass } \\
\text { index (BMI) } \\
\text { affected CHD } \\
\text { in women } \\
\text { over a } 10.9 \\
\text { mean year } \\
\text { period. }\end{array}$ & $\begin{array}{l}\text { Completed a } \\
\text { prospective cohort } \\
\text { study of } 38,987 \\
\text { from a recent } \\
\text { completed double } \\
\text { blinded } \\
\text { randomized } \\
\text { clinical trial the } \\
\text { Women's Health } \\
\text { Study. The mean } \\
\text { age was } 54 \text { years. } \\
\text { The data was } \\
\text { collected from } \\
\text { participants of the } \\
\text { WHS trial. }\end{array}$ & & $\begin{array}{l}\text { The study } \\
\text { concluded } \\
\text { that the more } \\
\text { overweight or } \\
\text { obese and the } \\
\text { lack of } \\
\text { physical } \\
\text { activity do } \\
\text { increase ones } \\
\text { risk of } \\
\text { developing } \\
\text { CAD. }\end{array}$ & $\begin{array}{l}\text { The strengths } \\
\text { of the study } \\
\text { were } \\
\text { comparable } \\
\text { groups, clear } \\
\text { outcomes, and } \\
\text { confounders } \\
\text { were identified. } \\
\text { The } \\
\text { weaknesses } \\
\text { were: no clear } \\
\text { question was } \\
\text { used, the self- } \\
\text { reported } \\
\text { physical } \\
\text { activity data } \\
\text { and } \\
\text { occupational } \\
\text { physical } \\
\text { activity was } \\
\text { not reported. }\end{array}$ \\
\hline
\end{tabular}




\begin{tabular}{|c|c|c|c|c|c|}
\hline Citation & $\begin{array}{l}\text { Aims, } \\
\text { Research } \\
\text { Questions or } \\
\text { Hypotheses }\end{array}$ & $\begin{array}{l}\text { Methodology: } \\
\text { Design, Site, } \\
\text { Sample }\end{array}$ & $\begin{array}{l}\text { Variables } \\
\text { and } \\
\text { Instrume } \\
\text { nts }\end{array}$ & Results & $\begin{array}{l}\text { Strengths and } \\
\text { Limitations }\end{array}$ \\
\hline $\begin{array}{l}\text { Chaitman } \\
\text { et al. } \\
\text { (1994) }\end{array}$ & $\begin{array}{l}\text { The aim of the } \\
\text { study was to } \\
\text { determine if } \\
\text { gender-based } \\
\text { differences } \\
\text { exist in the } \\
\text { post-test } \\
\text { management } \\
\text { and clinical } \\
\text { outcomes of } \\
\text { patients with } \\
\text { clinically } \\
\text { suspected } \\
\text { CAD. }\end{array}$ & $\begin{array}{l}\text { Conducted a } \\
\text { retrospective } \\
\text { cohort study on } \\
872 \text { middle-aged } \\
\text { patient's age } 45- \\
65 \text { years ( } 47 \% \\
\text { women and } 53 \% \\
\text { men) that were } \\
\text { referred to out- } \\
\text { patient testing } \\
\text { centers at St Louis } \\
\text { University Health } \\
\text { Science Center. }\end{array}$ & & $\begin{array}{l}\text { The study } \\
\text { concluded } \\
\text { that following } \\
\text { non-invasive } \\
\text { stress test, } \\
\text { women } \\
\text { having similar } \\
\text { rates of } \\
\text { angina, } \\
\text { cardiac risk } \\
\text { factors, and } \\
\text { positive stress } \\
\text { test were less } \\
\text { likely to } \\
\text { receive } \\
\text { additional } \\
\text { tests or } \\
\text { interventions } \\
\text { and died more } \\
\text { frequently } \\
\text { than men in a } \\
\text { two year } \\
\text { follow up } \\
\text { evaluation. }\end{array}$ & $\begin{array}{l}\text { The strengths } \\
\text { of the study } \\
\text { were clearly } \\
\text { focused } \\
\text { question, } \\
\text { comparable } \\
\text { groups, } \\
\text { confounders } \\
\text { defined, } \\
\text { outcomes and a } \\
\text { large } \\
\text { heterogeneous } \\
\text { group. } \\
\text { Weaknesses } \\
\text { were could not } \\
\text { find reference } \\
\text { to blinding, } \\
\text { data was only } \\
\text { collected from } \\
\text { one facility and } \\
\text { may not reflect } \\
\text { results of other } \\
\text { facilities. }\end{array}$ \\
\hline
\end{tabular}




\begin{tabular}{|c|c|c|c|c|c|}
\hline Citation & $\begin{array}{l}\text { Aims, } \\
\text { Research } \\
\text { Questions or } \\
\text { Hypotheses }\end{array}$ & $\begin{array}{l}\text { Methodology: } \\
\text { Design, Site, } \\
\text { Sample }\end{array}$ & $\begin{array}{l}\text { Variables } \\
\text { and } \\
\text { Instrume } \\
\text { nts }\end{array}$ & Results & $\begin{array}{l}\text { Strengths and } \\
\text { Limitations }\end{array}$ \\
\hline $\begin{array}{l}\text { Gao et al. } \\
\text { (1997) }\end{array}$ & $\begin{array}{l}\text { The aim of the } \\
\text { study was to } \\
\text { determine why } \\
\text { patients who } \\
\text { have had a MI } \\
\text { delayed } \\
\text { coming to the } \\
\text { hospital. }\end{array}$ & $\begin{array}{l}\text { Completed a } \\
\text { retrospective chart } \\
\text { review of } 2,409 \\
\text { patients in } 37 \\
\text { hospitals in } \\
\text { Minnesota. Mean } \\
\text { age was } 60 \text { years } \\
\text { of age with } 1,487 \\
\text { males and } 922 \\
\text { females. }\end{array}$ & & $\begin{array}{l}\text { Factors that } \\
\text { affect the } \\
\text { decision to } \\
\text { seek medical } \\
\text { attention is } \\
\text { advanced age, } \\
\text { female } \\
\text { gender, } \\
\text { attempts to } \\
\text { self-treat, } \\
\text { extended } \\
\text { decision } \\
\text { process, and } \\
\text { underuse of } \\
\text { emergency } \\
\text { medical } \\
\text { services. }\end{array}$ & $\begin{array}{l}\text { Strengths were: } \\
\text { a clearly } \\
\text { focused } \\
\text { question, } \\
\text { comparable } \\
\text { groups, CIs } \\
\text { were used, } \\
\text { outcomes were } \\
\text { clearly defined, } \\
\text { and } \\
\text { confounders } \\
\text { were identified. } \\
\text { Limitations } \\
\text { include relying } \\
\text { on } \\
\text { retrospective } \\
\text { chart review } \\
\text { for all data } \\
\text { used no access } \\
\text { to patient } \\
\text { provider to } \\
\text { obtain specific } \\
\text { information } \\
\text { that was not } \\
\text { included in the } \\
\text { patient's chart, } \\
\text { and limited to } \\
\text { one state. }\end{array}$ \\
\hline
\end{tabular}




\begin{tabular}{|c|c|c|c|c|c|}
\hline Citation & $\begin{array}{l}\text { Aims, } \\
\text { Research } \\
\text { Questions or } \\
\text { Hypotheses }\end{array}$ & $\begin{array}{l}\text { Methodology: } \\
\text { Design, Site, } \\
\text { Sample }\end{array}$ & $\begin{array}{l}\text { Variables } \\
\text { and } \\
\text { Instrume } \\
\text { nts }\end{array}$ & Results & $\begin{array}{l}\text { Strengths and } \\
\text { Limitations }\end{array}$ \\
\hline $\begin{array}{l}\text { Clark et } \\
\text { al. }(2005)\end{array}$ & $\begin{array}{l}\text { The aim of the } \\
\text { study was to } \\
\text { determine the } \\
\text { effectiveness } \\
\text { of secondary } \\
\text { cardiac } \\
\text { prevention } \\
\text { with and } \\
\text { without } \\
\text { exercise } \\
\text { components at } \\
12 \text { and } 24 \\
\text { months. }\end{array}$ & $\begin{array}{l}\text { Completed a meta- } \\
\text { analysis on } 63 \\
\text { randomized trials } \\
\text { that included } \\
21,295 \text { patients } \\
\text { with CAD. }\end{array}$ & $\begin{array}{l}\text { Dependent } \\
\text { variables } \\
\text { were: } \\
\text { incidence } \\
\text { of death } \\
\text { and MI. } \\
\text { Independe } \\
\text { nt } \\
\text { variables } \\
\text { were } \\
\text { programs } \\
\text { with } \\
\text { exercise, } \\
\text { without } \\
\text { exercise } \\
\text { and } \\
\text { exercise } \\
\text { only. }\end{array}$ & $\begin{array}{l}\text { Despite the } \\
\text { wide variety } \\
\text { of secondary } \\
\text { prevention } \\
\text { programs, all } \\
\text { programs } \\
\text { seem to } \\
\text { decrease the } \\
\text { incidence of } \\
\text { death and MI. }\end{array}$ & $\begin{array}{l}\text { Strengths were } \\
\text { a clearly } \\
\text { focused } \\
\text { question, } \\
\text { similar } \\
\text { treatment and } \\
\text { control groups, } \\
\text { and relevant } \\
\text { outcomes were } \\
\text { measured in a } \\
\text { standard } \\
\text { reliable way. } \\
\text { Significant } \\
\text { limitation in } \\
\text { the studies } \\
\text { were the lack } \\
\text { of blinding, } \\
\text { insufficient } \\
\text { details on } \\
\text { randomization, } \\
\text { or whether } \\
\text { allocation of } \\
\text { concealment } \\
\text { was achieved } \\
\text { in most trials }\end{array}$ \\
\hline
\end{tabular}




\begin{tabular}{|c|c|c|c|c|c|}
\hline Citation & $\begin{array}{l}\text { Aims, } \\
\text { Research } \\
\text { Questions or } \\
\text { Hypotheses }\end{array}$ & $\begin{array}{l}\text { Methodology: } \\
\text { Design, Site, } \\
\text { Sample }\end{array}$ & $\begin{array}{l}\text { Variables } \\
\text { and } \\
\text { Instrume } \\
\text { nts }\end{array}$ & Results & $\begin{array}{l}\text { Strengths and } \\
\text { Limitations }\end{array}$ \\
\hline $\begin{array}{l}\text { Curtis et } \\
\text { al. }(2002)\end{array}$ & $\begin{array}{l}\text { The aim of the } \\
\text { study was to } \\
\text { determine } \\
\text { there was a } \\
\text { difference } \\
\text { between } \\
\text { women and } \\
\text { men in the rate } \\
\text { of } \\
\text { percutaneous } \\
\text { intervention } \\
\text { (PCI) or } \\
\text { cardiac bypass } \\
\text { graft (CABG) } \\
\text { surgery } \\
\text { following } \\
\text { cardiac } \\
\text { catheterization } \\
\text {. }\end{array}$ & $\begin{array}{l}\text { Completed a } \\
\text { cohort study with } \\
\text { prospective data } \\
\text { collection of } \\
21,816 \text { patients in } \\
\text { Alberta Canada. } \\
\text { The study } \\
\text { included } 6,407 \\
\text { women and } \\
15,409 \text { men. }\end{array}$ & & $\begin{array}{l}\text { The extent of } \\
\text { CAD } \\
\text { accounted for } \\
\text { almost all of } \\
\text { the } \\
\text { differences in } \\
\text { the relative } \\
\text { risk } \\
\text { adjustment } \\
\text { model. }\end{array}$ & $\begin{array}{l}\text { Strengths of } \\
\text { the study were } \\
\text { CIs were used, } \\
\text { the groups } \\
\text { were } \\
\text { comparable, } \\
\text { and } \\
\text { confounders } \\
\text { were identified. } \\
\text { Weaknesses } \\
\text { were: clearly } \\
\text { focused } \\
\text { question, } \\
\text { interpreting the } \\
\text { results of the } \\
\text { study was } \\
\text { difficult and } \\
\text { can be easily } \\
\text { misinterpreted. }\end{array}$ \\
\hline
\end{tabular}




\begin{tabular}{|c|c|c|c|c|c|}
\hline Citation & $\begin{array}{l}\text { Aims, } \\
\text { Research } \\
\text { Questions or } \\
\text { Hypotheses }\end{array}$ & $\begin{array}{l}\text { Methodology: } \\
\text { Design, Site, } \\
\text { Sample }\end{array}$ & $\begin{array}{l}\text { Variables } \\
\text { and } \\
\text { Instrume } \\
\text { nts }\end{array}$ & Results & $\begin{array}{l}\text { Strengths and } \\
\text { Limitations }\end{array}$ \\
\hline $\begin{array}{l}\text { Goldberg } \\
\text { et al. } \\
(2001)\end{array}$ & $\begin{array}{l}\text { The aim of the } \\
\text { study was to } \\
\text { determine if } \\
\text { there was an } \\
\text { interaction } \\
\text { between the } \\
\text { participant's } \\
\text { sex and age } \\
\text { with a two } \\
\text { year follow-up } \\
\text { on mortality } \\
\text { and morbidity. }\end{array}$ & $\begin{array}{l}\text { Conducted a } \\
\text { cohort study to } \\
\text { determine whether } \\
\text { an interaction } \\
\text { between sex and } \\
\text { age affects } \\
\text { mortality and } \\
\text { morbidity two } \\
\text { years following a } \\
\text { myocardial } \\
\text { infarction. }\end{array}$ & & $\begin{array}{l}\text { The results of } \\
\text { the study } \\
\text { found that } \\
\text { women at age } \\
\text { sixty and } \\
\text { younger had a } \\
\text { higher } \\
\text { mortality rate } \\
\text { than men } \\
28.9 \% \text { to } \\
\text { 19.6\% } \\
\text { respectively. } \\
\text { However, } \\
\text { after age } \\
\text { sixty, the rate } \\
\text { of mortality in } \\
\text { women } \\
\text { compared to } \\
\text { men } \\
\text { decreased } \\
\text { with } \\
\text { increasing age } \\
\text { among the } \\
\text { oldest } \\
\text { participants } \\
\text { with the } \\
\text { oldest men } \\
\text { actually } \\
\text { having a } \\
\text { higher rate of } \\
\text { mortality than } \\
\text { women } \\
\text { (P=0.009) }\end{array}$ & $\begin{array}{l}\text { The strengths } \\
\text { of the study } \\
\text { were a clearly } \\
\text { focused } \\
\text { question, } \\
\text { comparable } \\
\text { groups, CIs, } \\
\text { and } \\
\text { confounders. } \\
\text { One limitation } \\
\text { in the study } \\
\text { was the } \\
\text { availability of } \\
\text { information on } \\
\text { reproductive } \\
\text { history, } \\
\text { smoking status, } \\
\text { menopausal } \\
\text { status, or } \\
\text { behavioral and } \\
\text { psychological } \\
\text { status. }\end{array}$ \\
\hline
\end{tabular}




\begin{tabular}{|c|c|c|c|c|c|}
\hline Citation & $\begin{array}{l}\text { Aims, } \\
\text { Research } \\
\text { Questions or } \\
\text { Hypotheses }\end{array}$ & $\begin{array}{l}\text { Methodology: } \\
\text { Design, Site, } \\
\text { Sample }\end{array}$ & $\begin{array}{l}\text { Variables } \\
\text { and } \\
\text { Instrume } \\
\text { nts }\end{array}$ & Results & $\begin{array}{l}\text { Strengths and } \\
\text { Limitations }\end{array}$ \\
\hline $\begin{array}{l}\text { Krumhol } \\
\text { z et al. } \\
(2002)\end{array}$ & $\begin{array}{l}\text { The aim of the } \\
\text { study was to } \\
\text { determine if } \\
\text { there were } \\
\text { differences } \\
\text { between men } \\
\text { and women } \\
\text { who } \\
\text { underwent } \\
\text { cardiac } \\
\text { catheterization } \\
\text { following a } \\
\text { myocardial } \\
\text { infarction } \\
\text { (MI) and to } \\
\text { determine the } \\
\text { appropriatenes } \\
\text { s of the } \\
\text { procedure } \\
\text { using clinical } \\
\text { guidelines. }\end{array}$ & $\begin{array}{l}\text { The data was } \\
\text { evaluated from the } \\
\text { Cooperative } \\
\text { Cardiovascular } \\
\text { Project. }\end{array}$ & & $\begin{array}{l}\text { The analysis } \\
\text { found that } \\
\text { there was a } \\
\text { statistical } \\
\text { difference } \\
\text { between men } \\
\text { and women } \\
\text { receiving } \\
\text { cardiac } \\
\text { catheterizatio } \\
\text { n following a } \\
\text { MI (46.5\% to } \\
35.7 \%) \\
\text { respectively } \\
\text { (p<0.001). }\end{array}$ & $\begin{array}{l}\text { The strengths } \\
\text { of the study } \\
\text { were a clearly } \\
\text { focused } \\
\text { question, } \\
\text { comparable } \\
\text { groups, clearly } \\
\text { defined } \\
\text { outcomes } \\
\text { identified, and } \\
\text { confounders } \\
\text { were identified. } \\
\text { Weaknesses of } \\
\text { the study were: } \\
\text { the } \\
\text { appropriateness } \\
\text { of } \\
\text { catheterization } \\
\text { was based on a } \\
\text { clinical } \\
\text { guideline, not } \\
\text { from causes of } \\
\text { mechanical } \\
\text { defect } \\
\text { guidelines for } \\
\text { catheterization } \\
\text { may not reflect } \\
\text { EBP standards, } \\
\text { relied on } \\
\text { retrospective } \\
\text { abstraction of } \\
\text { medical } \\
\text { records and } \\
\text { may have } \\
\text { missed } \\
\text { undocumented } \\
\text { clinical } \\
\text { indications for } \\
\text { catheterization. }\end{array}$ \\
\hline
\end{tabular}




\section{Appendix B}

\section{Capstone Budget}

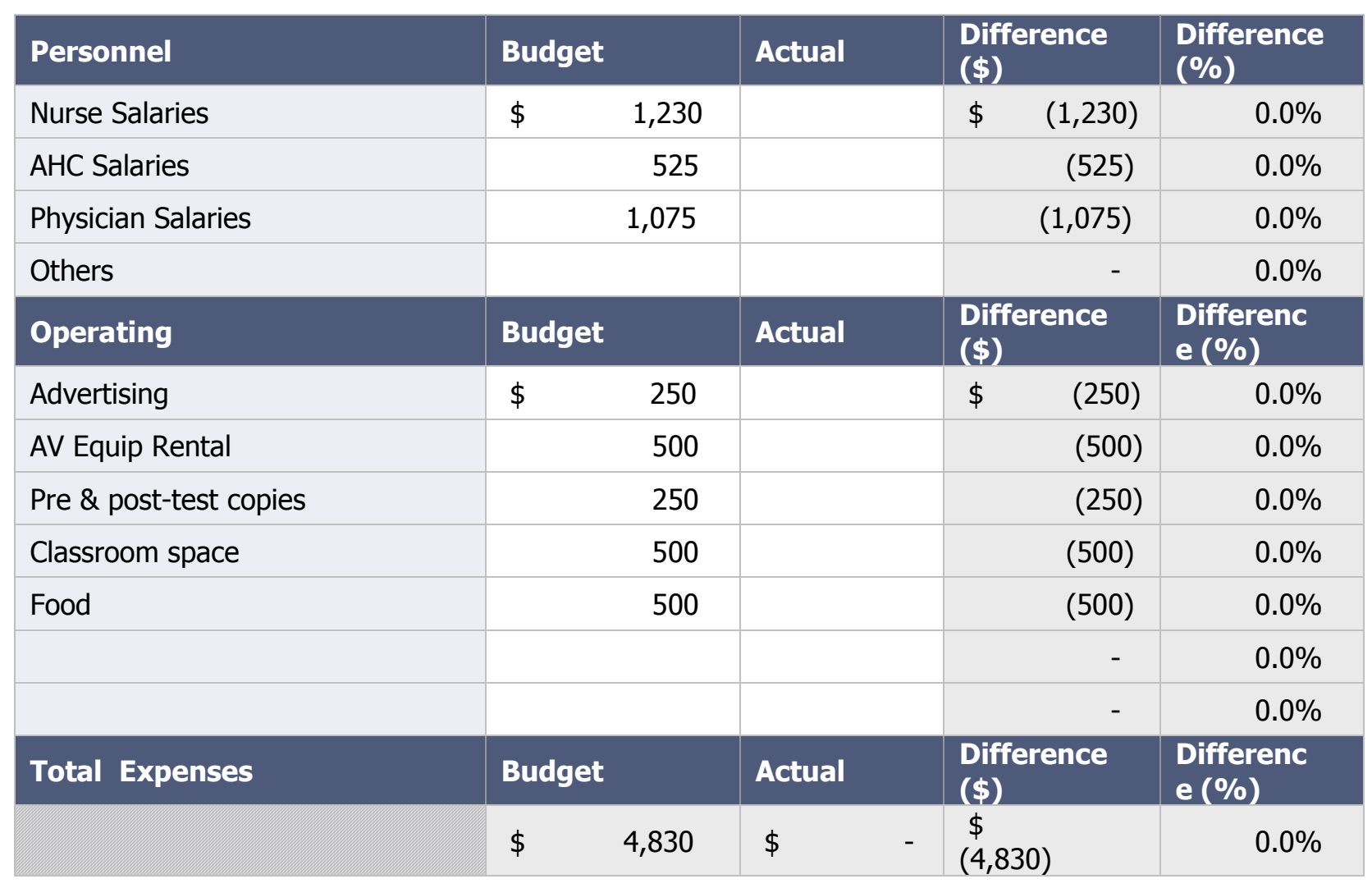




\section{Appendix C}

\section{Facility Support Letter}

\section{TLPRINCETON}

April 11, 2012

Robert E. Wynn, Jr

MSN, FNP-BC, CEN

DNP Student

West Virginia University

Dear Mr. Wynn,

Princeton Community Hospital is pleased to support your Capstone Proposal: A plan to recognize and speed the treatment in women who present to the ED with atypical signs and symptoms of acute coronary syndrome. Given the incidence of coronary artery disease that is seen in this hospital we would welcome the opportunity to assist you in this project.

Please let me know how the clinical and management staff can assist you in this very important project.

Sincerely,

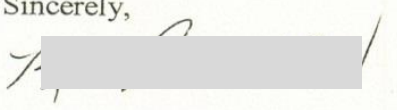

Kim Poe, RN, BSN

Director of Emergency Services, Employee Health, ICU and CCU

Princeton Community Hospital

$12^{\text {th }}$ Street Ext

Princeton, WV 24740

$304-487-7442$ 


\section{Appendix D}

\section{Pre-Test / Post-Test}

\section{Pre-Test for ACS in Women}

Provider Education Session

1- Who is responsible for delays in the treatment of women with ACS?
a. Women
b. Nurses
c. ED Providers
d. All the above

2- What are the atypical signs and symptoms with which women present to the ED?
a. SOB
b. Palpitations
c. Fatigue
d. New onset of weakness
e. All the above

3- What are the CORE values that are assessed with patients with c/o chest pain in the ED?
a. Door to NTG
b. Door to TNKase
c. Door to EKG
d. $\mathrm{B} \& \mathrm{C}$

4- What will not help decrease morbidity and mortality in women who present with ACS?
a. Decrease in delays
b. Administering ASA
c. Administering TNKase in less than 30 minutes (door to thrombolytic)
d. Starting two IV's of NS

5- What is the most typical presentation of women with ACS?
a. STEMI
b. Non - STEMI
c. Unstable angina
d. Have a positive coronary angiography

6- Men with chest pain are treated more rapidly in the ED than women.
a. True
b. False

7- Women are just as likely to receive PCI or CABG as men.
a. True
b. False 
8- There is no difference in the treatment of men and women with ACS no matter what their insurance is.

a. True

b. False

9- What types of reasons do women have for not seeking treatment when they develop chest pain?

a. House work needing to be done

b. Cooking dinner for the family

c. Need to care for other sick family members

d. All the above

10- How can a provider ensure they are treating women with ACS correctly?

a. Reading up to date evidence based practice guidelines

b. Asking the charge nurse or ED medical director

c. Doing what we "always do"

d. Watching your favorite TV medical show

11- Who on the ED team can help reduce delays in the treatment and care of women with ACS?
a. Women
b. Nurses
c. Providers
d. All of the Above

12- What are typical signs and symptoms of ACS that patients present with?
a. Chest pain
b. SOB
c. Pain radiating to left shoulder
d. All of the above

13- Choose all of the following that are not CORE measures as related to ACS patients.

a. Complete all documentation before the patient leave the ED

b. $\mathrm{O} 2$ at $2 \mathrm{~L} \mathrm{NC}$

c. Administration of Morphine for chest pain

d. All of the above

14- What is not part of ACS?
a. Unstable angina
b. Dyspnea
c. STEMI
d. Non-STEMI 
15- What are some nursing and medical provider's attitudes towards women with chest pain?
a. It's just anxiety
b. She is just crazy
c. She just wants attention
d. All of the above

16- EMS personnel are more aware that women present with atypical sign and symptoms of ACS than ED personnel. Choose the best answer.
a. True
b. False
c. Are equally unaware
d. None of the above

17- Preventing delays in the treatment of ACS decreases?
a. Death
b. Morbidly
c. Mortality
d. all of the above

18- What is the most effective way to get the message out about women with ACS?
a. TV ads
b. A short one on one education and counseling intervention
c. Newspaper articles
d. Nursing and medical journals

19- Higher perceived control over cardiac illness in women was associated with?
a. Attitude
b. Beliefs
c. Knowledge
d. All of the above

20- Women that are Dx with ACS and undergo percutaneous coronary intervention are less likely to receive.
a. Aspirin
b. Glycoprotein IIb/IIIa inhibitors
c. Nitroglycerine
d. All of the above 


\section{Post-Test for ACS in Women \\ Provider Education Session}

1- Who is responsible for delays in the treatment of women with ACS?
a. Women
b. Nurses
c. ED Providers
d. All the above

2- What are the atypical signs and symptoms with which women present to the ED?
a. SOB
b. Palpitations
c. Fatigue
d. New onset of weakness
e. All the above

3- What are the CORE values that are assessed with patients with c/o chest pain in the ED?
a. Door to NTG
b. Door to TNKase
c. Door to $\mathrm{EKG}$
d. $\quad B \& C$

4- What will not help decrease morbidity and mortality in women who present with ACS?
a. Decrease in delays
b. Administering ASA
c. Administering TNKase in less than 30 minutes (door to thrombolytic)
d. Starting two IV's of NS

5- What is the most typical presentation of women with ACS?
a. STEMI
b. Non - STEMI
c. Unstable angina
d. Have a positive coronary angiography

6- Men with chest pain are treated more rapidly in the ED than women.
a. True
b. False

7- Women are just as likely to receive PCI or CABG as men.
a. True
b. False 
8- There is no difference in the treatment of men and women with ACS no matter what their insurance is.
a. True
b. False

9- What types of reasons do women have for not seeking treatment when they develop chest pain?

a. House work needing to be done

b. Cooking dinner for the family

c. Need to care for other sick family members

d. All the above

10- How can a provider ensure they are treating women with ACS correctly?

a. Reading up to date evidence based practice guidelines

b. Asking the charge nurse or ED medical director

c. Doing what we "always do"

d. Watching your favorite TV medical show

11-Who on the ED team can help reduce delays in the treatment and care of women with ACS?
a. Women
b. Nurses
c. Providers
d. All of the Above

12- What are typical signs and symptoms of ACS that patients present with?
a. Chest pain
b. SOB
c. Pain radiating to left shoulder
d. All of the above

13- Choose all of the following that are not CORE measures as related to ACS patients.
a. Complete all documentation before the patient leave the ED
b. $\mathrm{O} 2$ at $2 \mathrm{~L} \mathrm{NC}$
c. Administration of Morphine for chest pain
d. All of the above

14- What is not part of ACS?
a. Unstable angina
b. Dyspnea
c. STEMI
d. Non-STEMI 
15- What are some nursing and medical provider's attitudes towards women with chest pain?
a. It's just anxiety
b. She is just crazy
c. She just wants attention
d. All of the above

16- EMS personnel are more aware that women present with atypical sign and symptoms of ACS than ED personnel. Choose the best answer.
a. True
b. False
c. Are equally unaware
d. None of the above

17- Preventing delays in the treatment of ACS decreases?
a. Death
b. Morbidly
c. Mortality
d. all of the above

18- What is the most effective way to get the message out about women with ACS?
a. TV ads
b. A short one on one education and counseling intervention
c. Newspaper articles
d. Nursing and medical journals

19- Higher perceived control over cardiac illness in women was associated with?
a. Attitude
b. Beliefs
c. Knowledge
d. All of the above

20- Women that are Dx with ACS and undergo percutaneous coronary intervention are less likely to receive.
a. Aspirin
b. Glycoprotein IIb/IIIa inhibitors
c. Nitroglycerine
d. All of the above 